Portland State University

PDXScholar

2016

\title{
Mindfulness-Based Stress Reduction (MBSR) as an Alternative Therapy for Chronic Pain
}

Kayla Ohlgren

Portland State University

Follow this and additional works at: https://pdxscholar.library.pdx.edu/honorstheses Let us know how access to this document benefits you.

\section{Recommended Citation}

Ohlgren, Kayla, "Mindfulness-Based Stress Reduction (MBSR) as an Alternative Therapy for Chronic Pain" (2016). University Honors Theses. Paper 352.

https://doi.org/10.15760/honors.346

This Thesis is brought to you for free and open access. It has been accepted for inclusion in University Honors Theses by an authorized administrator of PDXScholar. Please contact us if we can make this document more accessible: pdxscholar@pdx.edu. 
Mindfulness-Based Stress Reduction (MBSR) as an Alternative Therapy for Chronic Pain

By

\section{Kayla Ohlgren}

An undergraduate honors thesis submitted in partial fulfillment of the requirements for the degree of

Bachelor of Science

in

University Honors

and

Psychology

Thesis Advisor

Tina Burdsall

Portland State University

2016 


\begin{abstract}
This thesis discusses the possibility of Mindfulness-Based Stress Reduction (MBSR) as an alternative therapy for chronic pain compared to traditional medical care. It examines 18 peerreviewed scholarly articles and identifies benefits for chronic pain patients in terms of pain severity, quality of life, psychological distress, and duration of benefits. This thesis also identifies practical benefits of MBSR such as cost, implementation, no negative side effects, and the creation of life-long skills to be used after treatment has ended. In conclusion, MindfulnessBased Stress Reduction (MBSR) is both a physically effective and cost effective therapy for individuals suffering from chronic pain, and should thus be provided as a treatment option for anyone with a chronic illness.
\end{abstract}




\section{Table of Contents}

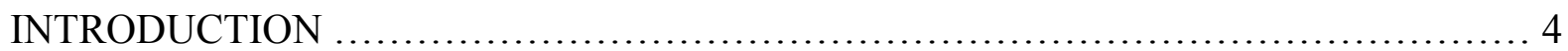

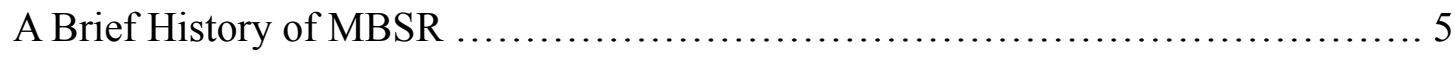

The Biopsychosocial Model $\ldots \ldots \ldots \ldots \ldots \ldots \ldots \ldots \ldots \ldots \ldots \ldots \ldots \ldots \ldots \ldots \ldots \ldots \ldots, 6$

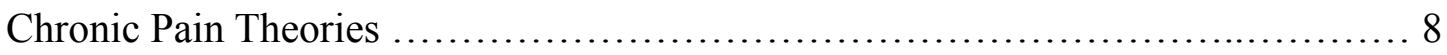

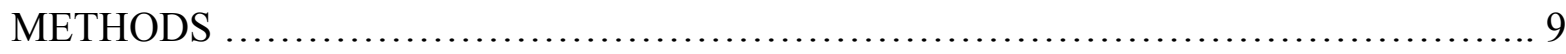

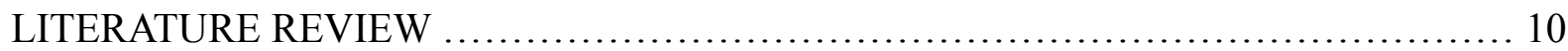

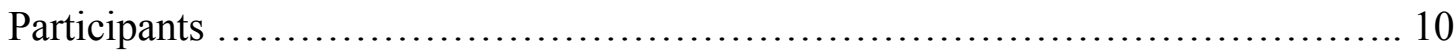

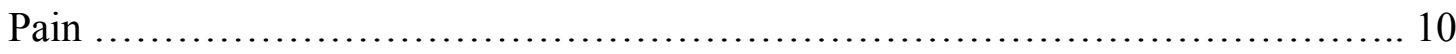

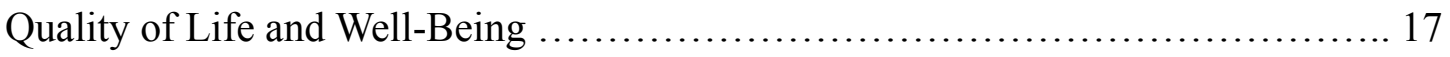

Psychological Distress .................................................. 21

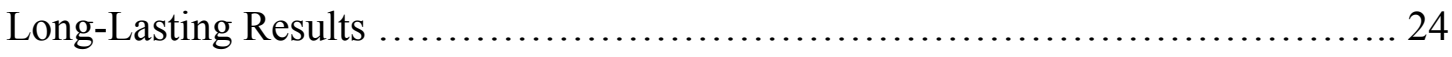

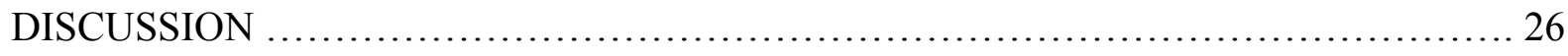

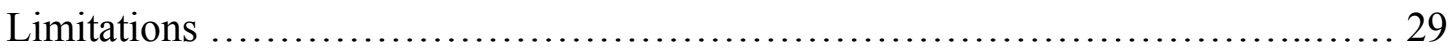

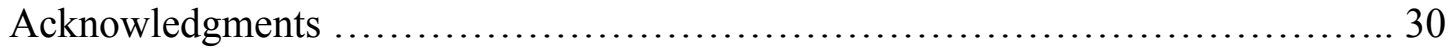

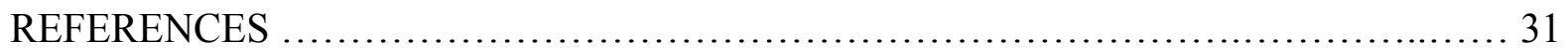

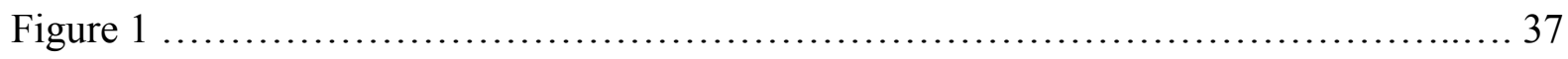

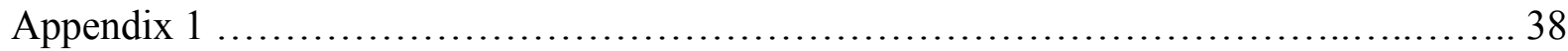

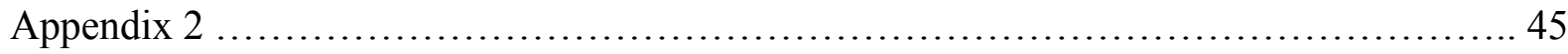

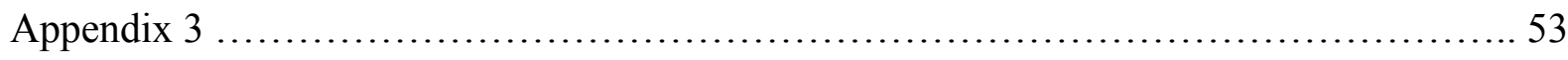




\section{INTRODUCTION}

According to the Institute of Medicine (IOM), chronic pain affects around 100 million American adults per year — more than the total number of adults affected by heart disease, cancer, and diabetes combined. At the same time, chronic pain costs the United States up to $\$ 635$ billion each year in medical treatment and lost productivity. Chronic pain is often defined as pain that persists for more than 12 weeks, which is very different from the normal sensation of acute pain that alerts our bodies to possible injury (Chronic Pain, 2011). There are a number of sources that may lead to chronic pain such as an initial injury (e.g., a back sprain), an ongoing cause (e.g., an illness), or there may be no distinguishable cause. In addition to the continual pain one experiences, individuals may also endure additional health problems that accompany chronic pain such as sleep disturbances, fatigue, mood changes, and decreased appetite. Furthermore, chronic pain can reduce flexibility, strength, and stamina by limiting a person's movements. The accumulation of physical discomfort brought on by chronic pain can make it difficult to fulfill enjoyable and important activities, which can lead sufferers of chronic pain to feel depressed and helpless.

Currently, chronic pain is largely treated with medication; but acupuncture, electrical stimulation, nerve blocks, or surgery may also be used (Chronic Pain, 2011). Even though those who suffer from chronic pain are fortunate to live in a time where many medications are widely available, many of the medications used (e.g., non-steroidal anti-inflammatory drugs and opiates) result in intolerable side effects. Physicians often have no choice but to advise their patients to learn to live with the pain (Morone et al., 2008). Because of the many millions of people who suffer from chronic pain in the United States alone, and the fact that many medications may not 
be worth taking due to their side effects or are difficult to afford, an alternative form of treatment is needed. Mindfulness-Based Stress Reduction (MBSR) is both a physically effective and cost effective therapy for individuals suffering from chronic pain, and should thus be provided as a treatment option for anyone with a chronic illness.

\section{A Brief History of MBSR}

Mindfulness meditation derives its roots from Buddhist Vipassana philosophy and has become a common practice within clinical psychology in Western societies (Banth \& Ardebil, 2015). Vipassana, meaning "to see things as they really are," is one of the most ancient meditation techniques from India. Gotama Buddha rediscovered Vipassana over 2500 years ago and taught it as a universal remedy for global ailments. Vipassana is a non-sectarian technique that teaches self-transformation through self-observation. Through disciplined attention to the physical sensations that form the life of the body, one can focus on the deep interconnection between mind and body. The aims of Vipassana are increased awareness, non-delusion, selfcontrol, and peace (Vipassana Meditation, n.d.). Based on these ideas, Mindfulness-Based Stress Reduction (MBSR) was born.

In 1979, an MIT-educated scientist named Jon Kabat-Zinn invented a form of treatment for chronic pain called Mindfulness-Based Stress Reduction (MBSR) at the Stress Reduction Clinic at the University of Massachusetts Medical Center. MBSR is an eight-week intensive training program that brings together mindfulness mediation and yoga (What is MindfulnessBased Stress Reduction, n.d.). According to Kabat-Zinn, mindfulness can be defined as "paying attention on purpose, in the present moment, and non-judgmentally, to the unfolding of 
experience moment to moment" (Kabat-Zinn, 2003, p. 145). During Kabat-Zinn's designed MBSR program, participants are to attend group classes that are two and a half hours in duration, once a week for eight weeks. In addition to attending the eight classes, participants are also instructed to practice daily home assignments for 45 to 60 minutes each day (MBSR 8-Week: How it works, n.d.). By cultivating greater awareness of the unity of mind and body, MBSR attempts to empower individuals to control and ease their own stress and/or pain. Since the advent of MBSR, scientists have proven that meticulous mindfulness training and mediation can lower cortisol levels and blood pressure, increase immune response, and may even affect gene expression (Pickert, 2014). Because MBSR is a promising therapy for chronic pain, it should be provided as a treatment option for individuals with chronic illnesses.

\section{The Biopsychosocial Model}

When examining chronic diseases, it is important to view them in the context of the biopsychosocial model. First proposed by George Engel (1977), the biopsychosocial model can be seen as a philosophy of clinical care as well as a practical clinical guide. On a philosophical level, physicians may use this model to understand how disease, illness, and suffering are affected on multiple levels, from societal levels to molecular levels of organization. Practically, this model allows physicians to understand a patient's subjective experience in order to provide an accurate diagnosis of their illness and to provide humane care, which contributes to the patient's health outcomes (Borrell-Carrio, 2004). The biopsychosocial model conceptualizes illnesses as an intricate interaction between biological factors, psychological factors, and social factors (Figure 1). 
Prior to the biopsychosocial model, scientists and doctors adhered to the biomedical model, stemming from Louis Pasteur's germ theory of disease. The biomedical model holds that biological factors are solely responsible for a person's illness. It excludes any symptoms that cannot be explained in biologic terms, leading to mind-body dualism where the mind and body are considered two separate entities (Johnson, 2012). The biomedical model was very successful in the beginning of the 20th century when the leading causes of death were pneumonia, influenza, tuberculosis, and diarrhea. All of these infectious diseases can be assessed in biological terms. By the end of the 20th century, however, people were dying from chronic diseases such as heart disease, cancer, and stroke. The biomedical model has failed to successfully address the modern health-care challenge of chronic disease and because chronic disease continues to be the primary cause of death for Americans today, the biopsychosocial model is finally becoming the accepted medical perspective when treating patients (Johnson, 2012).

This paradigm shift has even been implemented on a legislative level with the Affordable Care Act requiring that essential health benefits include mental health, preventive and wellness services, and chronic disease management. Furthermore, accredited medical schools must now teach patient-provider communication skills, the impact of patient culture and beliefs, the medical impact of common societal problems, and the impact of provider bias and beliefs (Johnson, 2012). The medical community has made large strides by embracing a medical model that encompasses biological, sociological, and psychological factors (i.e., the biopsychosocial model) compared to the outdated model physicians used to adhere by (i.e., the biomedical 
model). By understanding that the mind and body work together and even sometimes against one another, one can begin to understand the workings of MBSR.

\section{Chronic Pain Theories}

There are a number of theories that help explain why MBSR is an effective treatment for chronic pain, the first one being Gate Control Theory. The Gate Control Theory of pain proposes that non-painful inputs close the "gates" to painful inputs, preventing pain sensations from reaching the central nervous system. In this way, stimulation from non-noxious input can suppress pain (Melzack, 1965). In MBSR, meditation is the non-painful input that closes the gates to painful inputs. More specifically, emotional or conditioned responses to pain can be modified by meditation through disengaging habitual reactivity (Morone et al., 2008). In lay terms, a person is normally conditioned to react negatively to pain because the body does not like pain and is trained to alert the body whenever it experiences painful stimuli for self-survival. Through meditation, however, a person may retrain their body's response to pain so that instead of reacting to pain in a typical manner (e.g., becoming stressed or anxious), the person reacts by acknowledging that the pain is there but then let's the pain go and moves on. The person accepts that they are in pain but no longer experiences the psychological distress (e.g., anxiety, depression) that usually accompanies such pain. Meditation can be thought of as a barrier to pain by physically blocking the entrance to the area of the body where pain is registered. This theory suggests that pain signals can be inhibited or enhanced by psychological factors; meaning that the mind can change the way the brain processes pain. 
Another theory that can help explain how MBSR works is the Relaxation Response, which is a person's ability to boost their body's release of chemicals and brain signals that makes their organs and muscles slow down and increases blood flow to the brain. It can be thought of as the opposite reaction to the fight or flight response (Mitchell, 2013). When meditating, the body is basically experiencing the Relaxation Response. The person's breathing slows, their muscles loosen, and their heart rate decreases. This may be associated with the body releasing neurotransmitters and decreased muscle tension that are responsible for immediate pain relief (Morone et al., 2008).

The last theory that may explain why MBSR has positive affects on chronic pain is how our brain can physically change through meditation. For example, meditation experience is associated with increased cortical thickness. Magnetic Resonance Imaging (MRI) demonstrates how experienced meditators have thicker cortexes than individuals who do not practice meditation (Lazar et al., 2005). Another example showing how plastic our brains are is a study finding long-term meditation being associated with increased gray matter density in the brain stem (Vestergaard-Poulsen, 2009). The brain is extremely adaptable and can be altered with the right amount of time and practice. These results demonstrate how mindfulness meditation can physically change the brain in a number of ways. Perhaps through learning mindfulness techniques, the brain can physically change how it responds to painful stimuli.

\section{METHODS}

The research articles used in this examination were gathered using the PsychINFO and PubMed databases and GoogleScholar through Portland State University Library in the year of 
2016. All the cited articles pertaining to MBSR treatment on chronic pain patients were published between 2005 to 2016 in order to gather the most recent research available. Keywords employed while conducting a search within these parameters include mindfulness-based stress reduction, chronic pain, alternative therapy, chronic pain management, mindfulness meditation, and Jon Kabat-Zinn. Articles were then selected based on their relevance to the topic and their content. A few articles were selected based on their prevalence in the references of the research articles already chosen, whereby they were then located through the PsychINFO or PubMed databases or GoogleScholar.

\section{LITERATURE REVIEW}

\section{Participants}

From the 18 articles examined, most participants in these studies are female. Of the women participants, most of them are white, educated, and of good socioeconomic status. Half of the studies are conducted in the United States; four studies are implemented in the Middle East; and the remaining studies take place in Canada, Denmark, Germany, and Australia. The age range of the participants varies broadly from 18 to 75 with no children included in the studies (Appendix 3).

\section{Pain}

When deciding whether a therapy is a viable treatment for chronic pain, pain itself is probably the most important outcome measure to consider. If MBSR does not show positive affects on one's pain, then it should not be suggested as an alternative therapy to traditional 
medicine because it simply does not work. Thirteen of the eighteen articles display direct improvements in pain from MBSR treatment (Appendix 2), including improvements of pain on a number of pain questionnaires, pain indexes, and pain scales (i.e., McGill Pain Questionnaire, Pain Disability Index, Visual Analogue Pain Intensity Scale, Chronic Pain Acceptance Questionnaire-Revised, Graded Chronic Pain Scale, Chronic Pain Assessment Questionnaire, SF-36 Questionnaire, Irritable Bowel Symptom Severity Scale, Pain Perception Scale, Inventory of Pain Regulation) as well as self-reports of pain from patients (e.g., usually assessed with a zero to 10 numeric rating scale as is seen in Plews-Ogan et al.'s 2005 study). Improvements in pain are seen in diseases or illnesses such as pulmonary injury, chronic low back pain (CLBP), chronic tension-type headaches, chronic headaches/migraines, chronic leg pain, irritable bowel syndrome (IBS), fibromyalgia, breast cancer, and arthritis (Appendix 2).

From the articles that demonstrate results on pain, pain severity or pain intensity are primary outcomes that largely improve in a number of illnesses. In these 18 articles, pain severity and pain intensity are essentially the same outcome measures; some articles decided to use "severity" while others use "intensity." Effects on pain severity or intensity are important for anyone suffering from chronic pain because lowering the threshold for the pain a person feels on a daily basis can make life much more bearable and enjoyable. Patients with chronic back or neck pain, arthritis, fibromyalgia, tension headache, and IBS who practice MBSR see significantly greater improvements in their pain severity or intensity compared to control groups (Banth \& Ardebil, 2015; Cherkin et al., 2016; Garland, 2011; Omidi \& Zargar, 2014; Rosenzweig et al., 2010). Patients are able to reduce their pain by uncoupling the physical sensation from the emotional and cognitive experience of pain, as Kabat-Zinn et al. (1982) 
describe in their paper. In this way, we can see how the biopsychosocial model is crucial for the workings of MBSR because mindfulness meditation relies on both biological factors (i.e., the physical sensation) and psychological factors (i.e., the emotional and cognitive experience of pain). For example, patients are able to uncouple the different components of the experience of pain through breathing exercises, which leads them to focus on breathing rather than their pain; and mindful living, which makes them conscious of maladaptive coping strategies (Banth \& Ardebil, 2015).

MBSR also seeks to reduce reactivity to distressing feelings and thoughts that are associated with and amplify painful experiences. According to the biopsychosocial model, a person's health is comprised of both their physical and mental health; both being equally important. Moreover, physical health and mental health each affect one another. Reducing one's response to negative feelings and thoughts helps maintain a calm sense of self and can remind the individual that what they are actually experiencing is not as painful as they initially believed. Because our physical health is connected to our mental health, it is possible to decrease the physical amount of pain one is feeling through the power of the mind. When studying IBS, for instance, Garland (2011) found that mindfulness therapy leads to increased non-reactivity to cognitions, emotions, and physiological sensations; which results in decreased visceral sensitivity. Once visceral sensitivity is reduced, patients experience decreased severity of IBS symptoms.

Throughout the literature, one way to measure pain is by the level of pain a patient experiences, which can be articulated as pain level, pain score, or one's subjective rating of their pain. Patients are able to reduce their level of pain in a number of ways including distraction, 
increased body awareness, better coping skills, imagery, and meditation. Distraction, when employed in MBSR, is not used in the traditional sense of moving one's attention away from pain. Instead, patients in MBSR treatment are able to distract their minds from the pain they are experiencing by purposefully refocusing their attention on the present moment (Morone et al., 2008). An example can be as simple as a person with chronic pain washing the dishes. Before learning the tools associated with MBSR, the individual may not put much thought into washing the dishes and mindlessly perform the task while mainly focusing on their current pain. After learning how to become fully engaged with everyday activities, however, the person may become absorbed in this once mundane activity, which causes them to be distracted from their pain. Another example of distraction from pain is breathing exercises. By focusing on one's breathing, participants are able to engage in calming their bodies and are not focused on the pain (Banth \& Ardebil, 2015). In both of these examples, the individuals suffering from chronic pain are able to bridge together their mental and physical health, which improves their experience of pain. If the patients were adhering to the biomedical model, they would not be able to ease their suffering because the method of distraction cannot be explained in biologic terms.

Another way patients reduce their pain is by embracing all parts of their experience, including the pain. Just as the biopsychosocial model includes all factors that contribute to a person's life (i.e., biological, psychological, and sociological factors), MBSR encourages participants to accept all parts of their subjective experience. People may try to ignore their pain to get through the day as a coping mechanism; but attending to their pain, rather than ignoring it, is more effective at reducing pain. The goal is to help people handle their pain when it is an inevitable part of living, rather than feeling forced to accept the pain without a way to cope 
(Esmer et al., 2010). Acceptance of chronic pain is found to be inversely correlated with pain intensity, physical and psychosocial disability, pain-related anxiety, and depression while being directly correlated with improved work status and increased daily activity. Furthermore, believing that pain creates harm or disability can predict physical or psychosocial disability (Esmer et al., 2010). From these results, we can see how intricately the mind and body are connected. The simple change in one's perspective from ignoring their pain to accepting their pain can make a huge difference in the pain the person experiences.

Just as psychological factors are important when considering one's health, biological or physical factors are also important. By increasing their awareness of physical mechanisms (e.g., their surroundings, their bodies, their clothing), patients attend to their experience of pain, and thus embrace the pain (Morone et al., 2008). For instance, a patient with chronic lower back pain (CLBP) may want to begin their MBSR treatment but notice that they have a small pebble in their shoe, causing minor irritation. The individual can remove the pebble and eliminate the small source of discomfort and then begin her treatment with a clearer mind. Through MBSR, patients develop an increased awareness of subtle body sensations that enable them to recognize pain earlier than what they are used to, which in turn allows them to intervene before the pain escalates (e.g., removing the pebble from the shoe).

Another way patients may reduce their pain is through the body scan practice. The body scan encompasses both physical mechanisms (e.g., paying attention to different parts of the body) and psychological mechanisms (e.g., connecting what you are feeling to your body parts) and relates them to one another, which is an essential principle of the biopsychosocial model. When practicing the body scan, the person may lay down or sit upright and imagine taking a tour 
of their body. The goal is not to visualize or move one's body parts, but to experience each body part one by one. For example, patients usually start at the bottom end of their body, such as one of their feet and then move upward from there. Once the person scans over a body part, like their foot, they allow that part to fade from their awareness and move up to the next body part: the ankle, the calf, the knee, etc. until they reach their head. After scanning their head, they will connect their entire body together. The last step is feeling the skin around the entire body and noticing the sensations on the skin, such as the temperature or texture (Valentine, 2007).

During the body scan, patients may become cognizant of the interconnection between the body and their state of mind, which can then increases patients' self-control over their life. Moreover, while going through the body scan, most patients realize that not every part of their body is in pain. When experiencing chronic pain, it is relieving to know that only some aspects of their body hurt so they can focus on the ones that do not. For instance, if someone's back is hurting they can focus on their arm, which is not in pain, to both distract their mind from the pain and develop a feeling of gratitude for the rest of their body that is not in pain. Patients are able to recognize their real body conditions and to accept their chronic illnesses. By accepting their reality as it truly is and not trying to change it, patients alter their relationship with their body and pain (Banth \& Ardebil, 2015).

In Morone et al.'s (2008) study, patients may decrease their pain by increasing their insight into their negative emotional processing. They do this by recognizing that a specific body sensation is connected to a negative affective response that creates heightened pain. Negative affect, like fear or anxiety, have been shown to increase one's sensation of pain so changing such responses may reduce the experience of pain (Keefe, 2004). Like the biopsychosocial model 
suggests, the mind and body are intimately connected so that while one's body can affect how one feels, how one feels can also affect one's body. In the example of someone suffering from CLBP with a pebble in their shoe mentioned earlier, for instance, that person can begin to feel anxious when they notice pain in their foot. Though the pain is minor, they may begin to worry that they now have something wrong with their foot in addition to the back pain they already experience. Such worry and anxiety can exacerbate the minor foot pain they are experiencing along with their chronic back pain, making them feel worse. By becoming aware of the painful sensation in her foot being linked to anxiety and fear, the patient realizes that the negative emotions she is feeling are separate from the physical pain and thus modify those negative emotional responses. Lowering the level of anxiety and worry the patient feels can reduce the heightened sense of pain and with less pain clouding her mind, the patient can logically identify the initial source of her foot pain (i.e., the pebble).

In connection to negative emotional processing, participants also realize that they are suffering more from painful thoughts than from pain itself. In Banth \& Ardebil's (2015) study, participants are given information about the fundamentals of mindfulness; which include patience, compassion, non-striving, acceptance, curiosity, and being nonjudgmental toward one's thoughts/emotions/sensations as they arise. By practicing these mindfulness supporting attitudes, participants develop a wisdom and belief that their pain stems from their own thoughts, rather than from their body. This study asserts that psychological factors such as attitudes, beliefs, and emotions affect one's health, just as the biopsychosocial model proposes. Sometimes it is possible for individuals suffering from chronic pain to experience a reduction in pain by changing one's point of view rather than making physical changes (e.g., taking a medication). 


\section{Quality of Life and Well-Being}

Quality of life (QOL) is a broad multidimensional concept that includes subjective evaluations of both positive and negative aspects of life and can be thought of as the standard of health, comfort, and happiness a person or group experiences (HRQOL Concepts, 2016). Healthrelated quality of life (HRQOL) can be described as the aspects of overall quality of life that clearly affect a person's health, both physically and mentally (HRQOL Concepts, 2016). Wellbeing goes hand-in-hand with quality of life in that it is defined as a state of being comfortable, healthy, or happy, and it is a perception that one's life is going well (Well-Being Concepts, 2016). Both quality of life (including HRQOL) and well-being are important measure outcomes for a number of reasons: 1) Well-being integrates physical health (body) and mental health (mind), creating more holistic approaches to disease prevention and health promotion; 2) Wellbeing tells us how people are feeling from their perspective; 3) HRQOL is related to selfreported chronic diseases and their risk factors; and 4) By analyzing HRQOL surveillance data, experts can identify subgroups with poor perceived health and help implement interventions to better their situations and avoid more serious consequences (HRQOL Concepts, 2016). Because quality of life relies on one's health and a person's health is made up of biological, psychological, and sociological factors according to the biopsychosocial model, we may assume that biology, psychology, and social context are all contributing determinants of quality of life.

Quality of life is a major outcome measure that shows significant improvement from MBSR. From the 18 articles examined, 12 of them report improvements in patients' quality of life or well-being (Appendix 2). One way to measure quality of life is by whether an individual enjoys their life and if they feel positive about their life. Learning mindfulness meditation results 
in positive affect, mood improvement, the ability to derive joy and to relax, and engagement in life activities (Morone et al., 2008; Plews-Ogan et al., 2005; Grossman et al., 2007; Beaulac \& Bailly, 2015). These improvements on the psychological dimension of the biopsychosocial model demonstrate how health is complex and that a person's quality of life goes beyond their biological functioning to encompass many internal elements such as one's mood or thoughts.

Whether patients experience a reduction in the intensity of pain by direct alleviations of pain symptoms or by reinterpreting their pain sensations, their pain decreases. After experiencing constant pain for several months to a number of years, the reduction of pain will likely make patients better able to enjoy their lives, which can improve their mood and outlook on life. Furthermore, MBSR gives patients a tool to positively handle stress, which may be applicable to other aspects of their life besides the pain. In this way, MBSR can be thought of as more than just a treatment for chronic pain; it gives individuals the potential to make a shift in their mindset to improve their overall quality of life.

Beyond feeling better both emotionally and physically compared to how patients felt before starting MBSR treatment, patients are more willing to engage in life activities (e.g., music, exercise). MBSR gives patients tools to manage their chronic illness (e.g., relaxation techniques, yoga, meditation), which may feel incredibly empowering for those who may have previously felt like their disease just happened to them and they had no control over the pain or consequences stemming from it. If the power is put back into the hands of the patient, rather than in the hands of a doctor or a medication, patients may feel that they have more control over their lives and possibly develop the courage to engage in life activities they once participated in. Engaging in past hobbies or activities that one enjoys will likely yield benefits for one's health in 
terms of the psychological and social realm of the biopsychosocial model. Psychologically, a person usually partakes in hobbies that coincide with their personality, attitudes, and beliefs so being able to engage in such activities again may make the person feel like the person they were before being diagnosed with a chronic illness or perhaps more fulfilled, as they are able to do what they want to be doing. In terms of social context, many activities (e.g., gatherings at friend's houses, sports events, eating out) can be spent socially so being able to partake in activities that involve other people can strengthen social relationships, thus improving the social aspect of health.

Another benefit patients experience from practicing MBSR is an improvement in their ability to pay attention (Morone et al., 2008). MBSR teaches participants to fully engage with themselves and their surroundings and instead of ignoring unpleasant stimuli (e.g., the pain one experiences on a regular basis), to embrace and accept everything one encounters. Paying attention is a constant exercise in MBSR — from paying attention to what specifically might be hurting oneself (e.g., the position one is sitting in, if they exercised that day) to what techniques may alleviate pain (e.g., distracting oneself by watching TV, changing one's position). Attention skills are a critical aspect of MBSR and improve in a number of patients as they continue treatment. The increased attention patients acquire is also associated with a sense of well-being. In Morone et al.'s (2008) study, one patient remarks, “Learning mindfulness meditation helped me to be more relaxed and focused in day to day living" (p. 5). From the perspective of the biopsychosocial model, the patient mentioned in this study is an example of health being composed of both the mind and body. By improving their attention skills via their mind, the patient experienced physical changes in their body (e.g., being more relaxed). Better attention 
skills is another example of putting the power back into the hands of the patients and their quality of life should be enhanced as a result.

In a number of studies, quality of sleep or fatigue also improves from mindfulness meditation (Esmer et al., 2011; Rahmani et al., 2014; Morone et al., 2008). In Esmer et al.'s (2011) study, not only do Failed Back Surgery Syndrome (FBSS) patients experience improved sleep, but they are also able to reduce their insomnia medication consumption. In the FBSS population, duration of pain correlates with poor sleep quality and analgesic medications have proven adverse affects and financial cost, so the improvement of sleep quality and the reduction of insomnia medication is particularly relevant. According to a number of patients, sleep latency (the time from the decision to sleep to the onset of sleep) is also reduced and the sleep patients experience while practicing MBSR is more refreshing or restful. If patients wake up during the night at some point, they report that they are able to go back to sleep more easily than before the treatment began (Morone et al., 2008). From the biopsychosocial model lens, we can see how the mind and body are connected by mindfulness meditation (stemming from the mind) improving patients' quality of sleep (a physical process). By improving quality of sleep and lessening fatigue, patients' mood, behavior, and relationships with others may be positively affected because the patients should feel well rested rather than feeling groggy or irritable.

MBSR helps improve patients' well-being by improving their quality of sleep, reducing feelings of fatigue, and possibly affecting social aspects of one's life. As one patient in Morone et al.'s (2008) study puts it, “Sleeplessness was harming my quality of life in every aspect and I am grateful I no longer have the problem. It has made a huge difference in my life" (p. 5). Sleep is 
something many people take for granted, but when experiencing pain every day, sleep is especially important for one's quality of life.

\section{Psychological Distress}

Chronic illnesses often go hand-in-hand with psychological distress - unpleasant feelings or emotions that impact one's level of functioning. When faced with an obstacle like a chronic disease, it is understandable that some patients will experience depressive symptoms or anxiety. These individuals never asked for or expected that they would endure a chronic illness, which may understandably leave them with feelings of intense sadness and despair as to why this situation is happening to them. They also do not know if their pain will ever go away or if it will instead get worse, perhaps creating a sense of anxiousness about the future's uncertainty. Depression and anxiety can sometimes be mediated with medication, but alleviating the initial source of the psychological distress (i.e., the chronic illness) seems like an ideal plan of action. MBSR goes beyond the scope of medication by reducing psychological distress at an organic level. Of the 18 articles examined, 10 reported direct improvements in psychological distress (Appendix 2). In the selected articles, the authors define psychological distress largely in terms of depression and anxiety; while a couple of articles think of psychological distress as encompassing depression, anxiety, somatization, and a global severity index.

One's thoughts, emotions, and physical sensations are all connected; which results in the pain one experiences affecting their quality of life and psychological distress, and vice versa. Mindfulness therapy increases non-reactivity to cognitions, emotions, and physiological sensations; meaning that mindfulness practices train the mind to be calm and accepting of 
incoming stimuli rather than to overreact (Garland et al., 2011). In turn, the body experiences decreased visceral sensitivity. Through the biopsychosocial model, we can understand that the mind has a profound impact upon the body, so much so that it can even reduce physical pain. If a person who is experiencing pain does not react strongly to the pain, the body does not have a reason to react either so the potential amount of pain the person can experience is lessened. Reductions in visceral sensitivity then reduce the symptoms of the chronic illness the person has, as in Garland et al.'s (2011) study when reductions in visceral sensitivity predicted decreased severity of IBS symptoms. Once a patient's symptoms are reduced, their quality of life may improve. The patient may feel that their life has improved because they are experiencing fewer symptoms of their chronic illness, which should reduce their feelings of psychological distress. The patient begins this process with their cognitions (i.e., by not reacting to them) and also ends the process with their thoughts (i.e., the thought of things improving), coming full circle.

According to the DSM-V (i.e., the latest edition of the Diagnostic and Statistical Manual of mental Disorders, which is used to classify mental disorders by mental health professionals in the United States), depression is defined as depressed mood or a loss of interest or pleasure in daily activities for more than two weeks. MBSR teaches participants techniques for selfobservation, acceptance, and thoughtful responses to pain. This design may disconnect the affective response to pain from ruminations about pain, and thus interrupt the development of depressive symptoms from occurring (Sephton et al., 2007). As mentioned earlier, MBSR allows individuals to change their lifestyle and thus changes how they view the world. In Sephton et al.'s (2007) study, fibromyalgia patients view their lives as more comprehensible, manageable, and meaningful after practicing MBSR. By viewing difficult events and circumstances in a more 
neutral, or even more positive light, somatic pain sensations are less likely to create affective responses to pain; meaning patients will have less depressive thoughts about their current situation.

When examining depressive symptoms, adherence to formal home meditation practice appears to play an important role. In Rosenzweig et al.'s (2010) study, chronic pain patients who consistently practice meditation at home have greater reductions in overall psychological distress and somatic symptoms, and a greater improvement in self-rated health compared to those who do not adhere to formal home meditation practice. Greater home practice is associated with an improvement in social functioning and a reduction in role limitations due to emotional problems. Pradhan et al.'s (2007) study has similar findings with rheumatoid arthritis patients. The greater the home practice (number of days per week), the greater improvement in psychological symptoms for patients. Furthermore, patients in Sephton et al.'s (2007) study who continue to meditate at the end of the study, compared to patients who do not, experience the greatest reduction in depressive symptoms. MBSR appears to be most effective for alleviating psychological distress, including depressive symptoms, when patients adhere to practicing meditation often and implementing it into their life after the treatment program has ended.

Anxiety makes up a large component of psychological distress, maybe especially for those with chronic pain. The thought of knowing that you will be in pain tomorrow, and the next day, and the day after can be extremely daunting and it is not surprising that someone can feel worried or uneasy about their future. Individuals with chronic pain may worry if they will be able to make it into work the next day, if they will be able to take care of their children in the future, or even simple tasks like being able to make it through a movie with their significant 
other. Fortunately, MBSR demonstrates its effectiveness on improving chronic pain patients' anxiety (Cherkin et al., 2016; Fjorback et al., 2013; Grossman et al., 2007; Schmidt et al., 2011). MBSR teaches patients a variety of techniques that can help reduce anxiety such as breathing techniques, yoga, meditation, and ways to combat stress. Patients are given the tools to learn how to react to stressful situations so when facing a difficult encounter, they are prepared. Once they engage in these techniques and see the positive results, patients may acquire more confidence in their own abilities and thus the uncertainty of the future becomes more clear. Moreover, because they learn these widely applicable practices, they can take them and continue to use them long after the treatment has ended.

\section{Long-Lasting Results}

Not only has MBSR produced significant outcomes on pain, quality of life and wellbeing, emotional/psychological distress, and mindfulness; but these results are also long lasting. In Cherkin et al.'s (2016) study on adults with chronic low back pain (CLBP), they find that MBSR results in greater improvement in back pain and functional limitations at 26 and 52 weeks when compared with usual care (i.e., received medical care they would normally receive and are free to seek whatever treatment, if any, they desired). These findings contrast with findings of their previous studies of massage, acupuncture, and yoga conducted in the same population as the MBSR trial. In the previous studies, treatment effects decrease between the end of treatment (8-12 weeks) and long-term follow-up (26-52 weeks). The current study suggests that MBSR may equip patients with the skills to have long lasting relief from their pain. 
Esmer et al.'s (2011) study on adults with Failed Back Surgery Syndrome (FBSS) further demonstrates the long lasting benefits of MBSR. In this study, the MBSR intervention group experiences statistically significant improvements in all outcome measures compared to the control group (i.e., usual medical care) at 12 weeks. The MBSR group maintains these gains from 12 to 40 weeks. Moreover, the Chronic Pain Assessment Questionnaire (CPAQ) score continues to improve during the 28-week interval after the MBSR intervention is completed. These results add to the discussion that MBSR may provide benefits of longer duration than traditional medical care.

Lastly, Grossman et al.'s (2007) study that implements MBSR in patients with fibromyalgia also presents long-term benefits for chronic pain sufferers. Compared to the control group, the MBSR group demonstrates significantly greater short-term and long-term benefits on most dimensions including visual analog pain, quality of life (QoL) subscales, coping with pain, depression, anxiety, and somatic complaints. What is most interesting about these results is how the MBSR group reports higher initial levels of pain at baseline compared to the control group, yet they outperform the control group at the two-week follow-up and even at the three-year follow-up. The findings of this study among the other studies previously mentioned shed light on the effectiveness of MBSR as a viable treatment for chronic pain in both the short-term and longterm.

There may be a number of reasons why MBSR yields long-term benefits to chronic pain patients. One possible explanation as to why MBSR provides long-lasting benefits can be rooted in MBSR's curriculum. MBSR teaches participants about techniques, practices, and perspectives that can be used in one's everyday life (e.g., meditation, breathing exercises, yoga). Furthermore, 
MBSR practitioners recommend that participants continue to practice such techniques (e.g., the take-home homework assignments usually assigned). In Grossman et al.'s (2007) study for example, more than three quarters of MBSR patients report maintaining some aspect of mindfulness practice 36 months after the study. Moreover, mindfulness training focuses on enabling patients to effectively manage the pain they are experiencing and thereby accept living with the pain. Instead of trying to reduce one's symptoms, patients learn to change their attitude and form a greater awareness, tolerance, and acceptance towards the unfortunate aspects of life. By experiencing this shift in their frame of mind, patients can use what they learn from MBSR to overcome future hardships.

\section{DISCUSSION}

In the context of the biopsychosocial model, we can see how MBSR is a form of treatment that encompasses biological factors (i.e., breathing exercises, yoga), psychological factors (i.e., mindfulness meditation, acceptance of pain), and sociological factors (i.e., group classes). By acknowledging that the mind and body are equally important aspects for an individual's health, MBSR is an inclusive, holistic approach to disease. MBSR has proven to be an effective therapy for individuals suffering from chronic pain on a number of dimensions including pain severity or level of pain, quality of life, psychological distress, and provides longlasting benefits (Appendix 2). From the articles examined, more than half of the articles demonstrate significant improvements on all three dimensions (Appendix 2). MBSR is a safe, affordable, and relatively easy therapy to implement that should be offered as an option of treatment to individuals suffering from a chronic disease. 
MBSR is a safe therapy because it does not cause adverse side effects like many medications (e.g., opiates and non-steroidal anti-inflammatory drugs). Instead, MBSR provides either positive effects on one's health, as seen in the literature above, or no effect (Appendix 2). Techniques such as breathing exercises, meditation, yoga, and the body scan are all gentle practices in which anyone can participate without injuring themselves. Furthermore, by teaching patients life-changing skills, they may feel like they are regaining control over their lives and thus feel empowered. Patients begin seeing the change in their mindset and how their thoughts and cognitions change the way their body responds physically. Because patients are taught valuable skills they can practice on their own, they are able to continue using mindfulness meditation even long after the treatment has ended. Unlike medications, which stop working once a person ceases taking them, MBSR has both short-term and long-term effects on chronic pain.

MBSR, however, does not alleviate symptoms for everyone and even when it reduces pain, it does not always eliminate the physical symptoms of the disease (e.g., in Arefnasab et al.'s 2013 study, patients with pulmonary injury experience improvements in pain but not in their lung function). For chronic conditions that do not benefit from MBSR on every dimension (e.g., such as physical symptoms), combining MBSR with traditional medical care may yield the best results for the patient. Because of the affordability of MBSR and it having no negative side effects, individuals with chronic illnesses may want to try MBSR as a form of treatment before opting for medicine or surgery. If MBSR does not provide the benefits the patient is looking for, the patient would be wise to adopt a traditional medical treatment plan or partake in MBSR in conjunction with traditional medicine. 
MBSR is also an affordable treatment plan for those with chronic illnesses, which makes the opportunity for treatment available to many Americans. The MBSR Program from UMASS Medical School ranges from $\$ 545$ to $\$ 725$ and is a one-time fee, unlike medication or doctor visits that require consistent payments. The program offers a sliding scale fee based upon an individual's income (e.g., tuition is $\$ 545$ for a household income less than $\$ 39,000, \$ 580$ for a household income of $\$ 40,000-\$ 49,000$, and $\$ 725$ for a household income of $\$ 50,000$ or greater) and payment plan options of six monthly payments or tuition assistance if needed (Tuition \& Payment Plans, n.d.). Considering that chronic pain costs the United States up to $\$ 635$ billion per year, which will be passed on to tax payers, a more affordable treatment option is beneficial to all Americans. The affordability of MBSR combined with its effectiveness on chronic pain makes it a treatment plan that can easily help millions of Americans who experience pain every day.

Implementation of MBSR is relatively simple because the program requires only one certified instructor to teach a group of patients in a class-like atmosphere and daily home assignments for patients to complete on their own. Patients may benefit from the class environment by relating to others who are facing similar situations. For instance, a patient suffering from chronic back pain may connect with another patient in the program who is suffering from fibromyalgia. Though they are not the same disease, both patients experience chronic pain and may understand what the other is going through. Patients may also benefit from having peers to talk to about their circumstances. For someone who experiences pain on a daily basis, they may not feel comfortable talking with their friends and family about how they are feeling. Perhaps they do not want to burden their loved ones with their pain or come off as being negative. Within the group, patients may feel more comfortable opening up about how they feel 
because they know that the other patients feel similarly. Having one instructor for a number of patients also makes MBSR more affordable than alternatives.

While MBSR is a straight-forward program that can be easily implemented, it is timeintensive. The program is comprised of eight classes ( $21 / 2$ hours per class, once a week for eight weeks) for a total of 31 hours of instruction, one all-day weekend class, and 45-60 minute home assignments that should be completed every day (MBSR 8-Week: How it works, n.d.). This does not include the time it takes to get to and from the class center as well. The substantial investment of time MBSR takes may be too intensive for some patients. Taking a medication that diminishes the same symptoms may seem like an easier treatment option that will not take as much time as partaking in an MBSR course.

Thus far, research on MBSR predominately involves upper-class, educated, white women. There is a large gap in the literature surrounding the lower class, minorities, men, and children. Also, much of the literature available takes place in the United States and the Middle East. More research is needed on people of lower socioeconomic status, ethnic minorities, men, and individuals under the age of 18. Research in countries besides the United States and Middle Eastern countries will also be beneficial for understanding if MBSR is an effective therapy for chronic pain in other countries and how cultural differences may or may not affect a person's response to treatment. MBSR is an effective treatment for chronic pain that is both affordable and relatively simple to implement. That being said, all populations should have equal access to this option of treatment.

\section{Limitations}


This thesis involves several limitations, one of them being that I did not conduct original research. With regard to time restraints, this being an undergraduate thesis, and the fact that I do not have formal training or certification in MBSR, conducting my own research seemed premature. While I have a theoretical understanding of MBSR I have not used MBSR in a clinical setting and therefore am limited in the practice and application of the therapy. I also did not compare MBSR to other alternative therapies (e.g., Cognitive Behavioral Therapy, Acceptance and Commitment Therapy, acupuncture) because I believe the results of MBSR are substantial enough by themselves for this thesis.

\section{Acknowledgments}

I would like to thank my Thesis Advisor Tina Burdsall for accepting me as one of her thesis students and for giving me constant support over the course of my writing. Tina helped me find a larger purpose for this thesis and without her, this thesis would not have been possible. 


\section{REFERENCES}

Arefnasab, Z., Ghanei, M., Noorbala, A. A., Alipour, A., Babamahmoodi, F., Babamahmoodi, A., Salehi, M. (2013). Effect of Mindfulness Based Stress Reduction on Quality of Life (SF-36) and Spirometry Parameters, in Chemically Pulmonary Injured Veterans. Iranian Journal of Public Health, 42(9), 1026-1033.

Banth, S. \& Ardebil, M. D. (2015). Effectiveness of mindfulness mediation on pain and quality of life of patients with chronic low back pain. International Journal of Yoga, 8(2), $128-133$.

Beaulac, J. \& Bailly, M. (2015). Mindfulness-based stress reduction: Pilot study of a treatment group for patients with chronic pain in a primary care setting. Primary Health Care Research \& Development, 16, 424-428.

Borrell-Carrio, F., Suchman, A. L., Epstein, R. M. (2004). The biopsychosocial model 25 years later: Principles, practice, and scientific inquiry. Annals of Family Medicine, 2(6), $576-582$.

Cathcart, S., Galatis, N., Immink, M., Proeve, M., Petkov, J. (2014). Brief mindfulness-based therapy for chronic tension-type headache: A randomized controlled pilot study. Behavioural and Cognitive Psychotherapy, 42, 1-15.

Cherkin DC, Sherman KJ, Balderson BH, et al. Effect of Mindfulness-Based Stress Reduction vs Cognitive Behavioral Therapy or Usual Care on Back Pain and Functional Limitations in Adults With Chronic Low Back Pain: A Randomized Clinical Trial. JAMA. 2016;315(12): $1240-1249$. 
Chronic Pain: Symptoms, Diagnosis, \& Treatment. (2011). NIH Medline Plus, 6(1), 5-6.

Retrieved from https://www.nlm.nih.gov/medlineplus/magazine/issues/spring11/articles/ spring 11pg5-6.html

Clinical Psychology. (N.d.). American Psychological Association. Retrieved from http:// www.apa.org/ed/graduate/specialize/clinical.aspx

Disability \& Socioeconomic Status. (N.d.). American Psychological Association. Retrieved from http://www.apa.org/pi/ses/resources/publications/disability.aspx

Esmer, G. E., Blum, J., Rulf, J., Pier, J. (2011). Mindfulness-based stress reduction for failed back surgery syndrome: A randomized controlled trial. Journal of the American Osteopathic Association 110(11), 646-652.

Fjorback, L. O., Arendt, M., Ornbol, E., Walach, H., Rehfeld, E., Schroder, A., Fink, P. (2013). Mindfulness therapy for somatization disorder and functional somatic syndromes Randomized trial with one-year follow-up. Journal of Psychosomatic Research 74, $31-40$.

Garland, E. L., Gaylord, S. A., Palsson, O., Faurot, K., Mann, J. D., Whitehead, W. E. (2012). Therapeutic mechanisms of a mindfulness-based treatment for IBS: effects on visceral sensitivity, catastrophizing, and affective processing of pain sensations. J Behav Med, 35(6), 591-602.

Grossman, P., Tiefenthaler-Gilmer, U., Raysz, A., Kesper, U. (2007). Mindfulness training as an intervention for fibromyalgia: Evidence of postintervention and 3-year follow-up benefits in well-being. Psychotherapy and Psychosomatics 76, 226-233. 
HRQOL Concepts. (2016). Centers for Disease Control and Prevention. Retrieved from http:// www.cdc.gov/hrqol/concept.htm

Johnson, S.B. (2012). Medicine's paradigm shift: An opportunity for psychology. American Psychological Association 43(8), 5.

Jon Kabat-Zinn. (N.d.). University of Massachusetts Medical School Center for Mindfulness in Medicine, Health Care, and Society. Retrieved from http:// www.umassmed.edu/cfm/about-us/people/2-meet-our-faculty/kabat-zinn-profile/

Kabat-Zinn J. An outpatient program in behavioral medicine for chronic pain patients based on the practice of mindfulness meditation: theoretical considerations and preliminary results. General Hospital Psychiatry 1982; 4:33-47.

Kabat-Zinn, J. (2003). Mindfulness-based interventions in context: Past, present, and future. Clinical Psychology: Science and Practice, 10(2), 144-156.

Keefe, F. J., Rumble, M. E., Scipio, C. D., Giordano, L. A., Perri, L. M. (2004). Psychological aspects of persistent pain: Current state of the science. J Pain 5, 195-211.

Lazar, S. W., Kerr, C. E., Wasserman, R. H., Gray, J. R., Greve, D. N., Treadway, M. T., McGarvey, M., Quinn, B.T., Dusek, J.A., Benson, H., Rauch, S.L., Moore, C.I., \& Fischl, B. (2005). Meditation experience is associated with increased cortical thickness. Neuroreport, 16(17), 1893-1897.

MBSR 8-Week: How it works. (N.d.). University of Massachusetts Medical School Center for Mindfulness in Medicine, Health Care, and Society. Retrieved from http:// www.umassmed.edu/cfm/stress-reduction/mbsr-8-week/

Melzack, R.W. (1965). Pain mechanisms: A new theory. Science, 150, 971-979. 
Mitchell, M. (2013). Dr. Herbert Benson's relaxation response. Psychology Today. Retrieved from https://www.psychologytoday.com/blog/heart-and-soul-healing/201303/dr-herbertbenson-s-relaxation-response

Morone, N. E., Lynch, C. S., Greco, C. M., Tindle, H. A., Weiner, D. K. (2008). "I felt like a new person." The effects of mindfulness meditation on older adults with chronic pain: qualitative narrative analysis of diary entries. The Journal of Pain: Official Journal of the American Pain Society, 9(9), 841-848.

Omidi, A., \& Zargar, F. (2014). Effect of mindfulness-based stress reduction on pain severity and mindful awareness in patients with tension headache: A randomized controlled clinical trial." Nursing and Midwifery Studies, 3(3).

Pickert, K. (2014). The art of being mindful. Time, 183(4), 40.

Plews-Ogan, M., Owens, J. E., Goodman, M., Wolfe, P., Schorling, J., (2005). A pilot study evaluating mindfulness-based stress reduction and massage for the management of chronic pain. Journal of General Internal Medicine, 20(12), 1136-1138.

Pradhan, E. K., Baumgarten, M., Langenberg, P., Handwerger, B., Gilpin, A. K., Magyari, T., Hochberg, M. C., Berman, B. M. (2007). Effect of Mindfulness-Based Stress Reduction in Rheumatoid Arthritis patients. Arthritis \& Rheumatism (Arthritis Care \& Research), 57(7), 1134-1142.

Rahmani, S., Talepasand, S., Ghanbary-Motlagh A. (2014). Comparison of Effectiveness of the Metacognition Treatment and the Mindfulness-Based Stress Reduction Treatment on Global and Specific Life Quality of Women with Breast Cancer. Iranian Journal of Cancer Prevention, 7(4), 184-196. 
Rosenzweig, S., Greeson, J. M., Reibel, D. K., Green, J. S., Jasser, S. A., Beasley, D. (2010). Mindfulness-based stress reduction for chronic pain conditions: Variation in treatment outcomes and role of home meditation practice. Journal of Psychosomatic Research 68, 29-36.

Schmidt, S., Grossman, P., Schwarzer, B., Jena, S., Naumann, J., Walach, H. (2011). Treating fibromyalgia with mindfulness-based stress reduction: Results from a 3-armed randomized controlled trial. PAIN 152, 361-369.

Sephton, S. E., Salmon, P., Weissbecker, I., Ulmer, C., Floyd, A., Hoover, K., Studts, J. L. (2007). Mindfulness meditation alleviates depressive symptoms in women with fibromyalgia: Results of a randomized clinical trial. Arthritis \& Rheumatism, 57(1), $77-85$

Tuition \& Payment Plans. (N.d.). University of Massachusetts Medical School Center for Mindfulness in Medicine, Health Care, and Society. Retrieved from http:// www.umassmed.edu/cfm/stress-reduction/mbsr-8-week/tuition--payment-plans/ Valentine, V. (2007). A crash course in body scan meditation. Oregon Public Broadcasting. Retrieved from http://www.npr.org/templates/story/story.php?storyId=7650123

Vestergaard-Poulsen, P., van Beek, M., Skewes, J., Bjarkam, C. R., Stubberup, M., Bertelsen, J., \& Roepstorff, A. (2009). Long-term meditation is associated with increased gray matter density in the brain stem. Neuroreport, 20(2), 170-174.

Vipassana Meditation. (N.d.). Retrieved from https://www.dhamma.org/en-US/about/vipassana Well-Being Concepts. (2016). Centers for Disease Control and Prevention. Retrieved from http:// www.cdc.gov/hrqol/wellbeing.htm 
What is Mindfulness-Based Stress Reduction? (N.d.). Mindful Living Programs. Retrieved from http://www.mindfullivingprograms.com/whatMBSR.php 


\section{Figure 1}

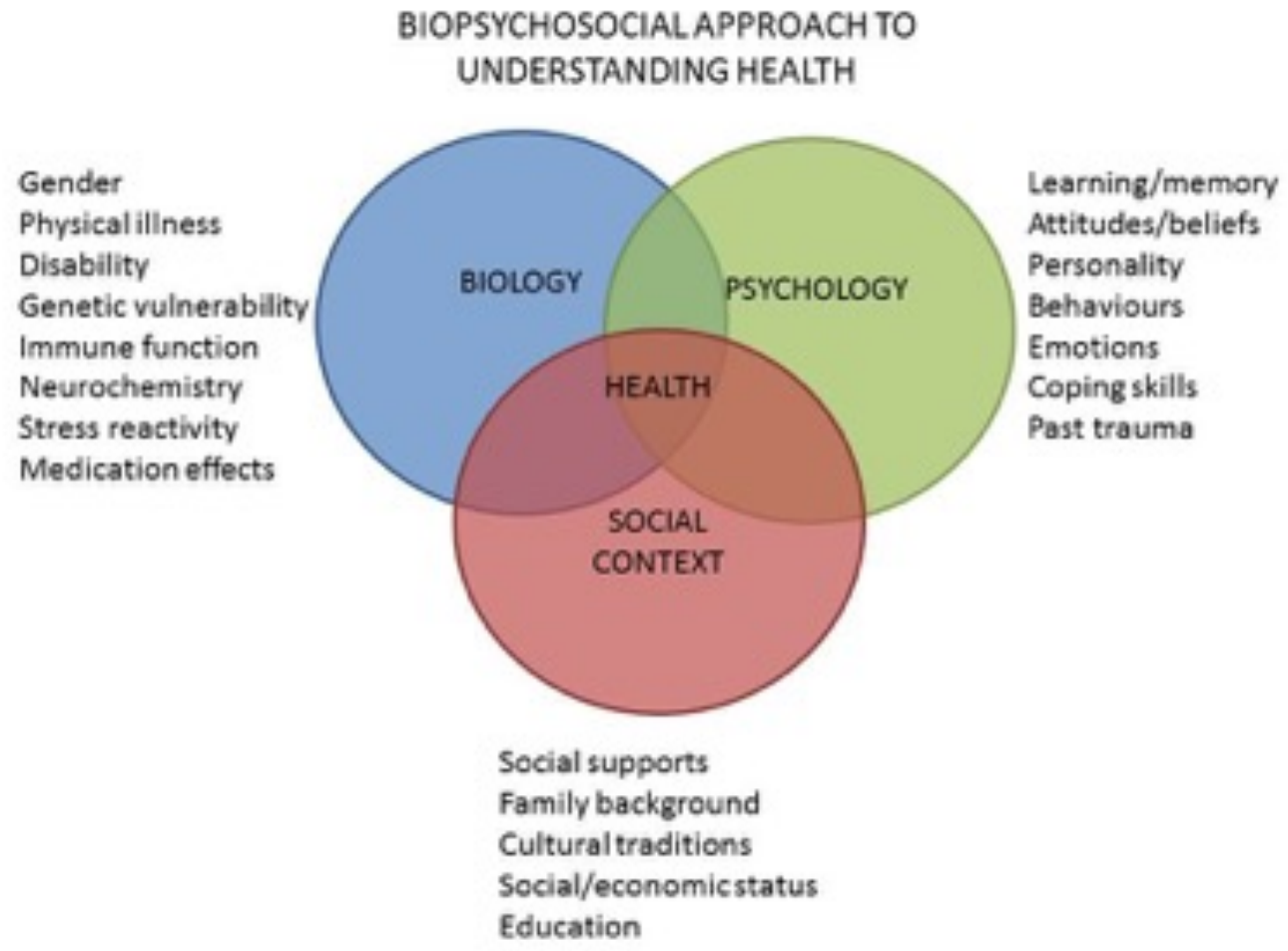

Note: This diagram was obtained from http://perspectivesclinic.com/health-psychology/ 


\section{Appendix 1: Primary results from MBSR studies}

\begin{tabular}{|c|c|c|c|c|}
\hline Article Citation & $\begin{array}{l}\text { Method of } \\
\text { Research }\end{array}$ & Sample & Main Findings & $\begin{array}{c}\text { Significance Levels } \\
\text { of Findings }\end{array}$ \\
\hline $\begin{array}{l}\text { Arefnasab, Z., Ghanei, } \\
\text { M., Noorbala, A. A., } \\
\text { Alipour, A., } \\
\text { Babamahmoodi, F., } \\
\text { Babamahmoodi, A., } \\
\text { Salehi, M. (2013). } \\
\text { Effect of Mindfulness } \\
\text { Based Stress Reduction } \\
\text { on Quality of Life } \\
\text { (SF-36) and } \\
\text { Spirometry Parameters, } \\
\text { in Chemically } \\
\text { Pulmonary Injured } \\
\text { Veterans. Iranian } \\
\text { Journal of Public } \\
\text { Health, 42(9), } \\
\text { 1026-1033. }\end{array}$ & $\begin{array}{l}2 \text { groups: control wait } \\
\text { list and MBSR. MBSR } \\
\text { received 8-weekly } \\
\text { sessions intervention. } \\
\text { Used SF-36 } \\
\text { questionnaire for } \\
\text { quality of life and } \\
\text { spirometry parameters } \\
\text { before and after } \\
\text { intervention. Used } \\
\text { mixed factorial } \\
\text { analyses of variance } \\
\text { test for analyzing data. } \\
\text { If there was a } \\
\text { significant } \\
\text { interactional effect, } \\
\text { they used paired } \\
\text { sample t-test and } \\
\text { independent sample t- } \\
\text { test. }\end{array}$ & $\begin{array}{l}40 \text { male pulmonary } \\
\text { injured veterans in } \\
\text { Tehran, Iran. }\end{array}$ & $\begin{array}{l}\text { MBSR can improve an } \\
\text { individual's quality of } \\
\text { life but not lung } \\
\text { function in chemically } \\
\text { pulmonary injured } \\
\text { veterans. }\end{array}$ & $\begin{array}{l}\text { The MBSR group } \\
\text { improved significantly } \\
\text { on the SF-36 total } \\
\text { score compared to the } \\
\text { WL condition. } \\
\text { Significant } \\
\text { improvements for the } \\
\text { MBSR compared to the } \\
\text { WL group were seen in } \\
\text { role limitations due to } \\
\text { physical problems } \\
\text { score, role limitations } \\
\text { due to emotional } \\
\text { problems score, social } \\
\text { functioning score, } \\
\text { mental health score, } \\
\text { vitality score, and pain } \\
\text { score. }\end{array}$ \\
\hline $\begin{array}{l}\text { Banth, S. \& Ardebil, } \\
\text { M. D. (2015). } \\
\text { Effectiveness of } \\
\text { mindfulness mediation } \\
\text { on pain and quality of } \\
\text { life of patients with } \\
\text { chronic low back pain. } \\
\text { International Journal } \\
\text { of Yoga, 8(2), 128-133. }\end{array}$ & $\begin{array}{l}2 \text { groups: control group } \\
\text { (usual medical care } \\
\text { only) and patients who } \\
\text { have been diagnosed as } \\
\text { nonspecific chronic } \\
\text { low back pain } \\
\text { (NSCLBP) by a } \\
\text { physician were } \\
\text { assigned to MBSR + } \\
\text { usual medical care } \\
\text { group. Patients were } \\
\text { assessed at } 3 \text { times by } \\
\text { Mac Gil pain and } \\
\text { standard brief quality } \\
\text { of life scales. Data was } \\
\text { analyzed by ANCOVA } \\
\text { using SPSS software. }\end{array}$ & $\begin{array}{l}88 \text { females aged } 30-45 \\
\text { who were diagnosed as } \\
\text { chronic NSLBP by } \\
\text { physicians in Ardebil- } \\
\text { Iran at least } 6 \text { months } \\
\text { before. Final sample } \\
\text { included } 48 \text { females. }\end{array}$ & $\begin{array}{l}\text { MBSR is an effective } \\
\text { intervention on } \\
\text { reducing pain severity } \\
\text { and improving physical } \\
\text { and mental quality of } \\
\text { life in female patients } \\
\text { with NSCLBP. }\end{array}$ & $\begin{array}{l}\text { Patients who received } \\
\text { MBSR plus usual } \\
\text { medical care reported } \\
\text { significantly lower } \\
\text { pain than patients } \\
\text { receiving only usual } \\
\text { medical care. The } \\
\text { intervention had an } \\
\text { effect on increasing the } \\
\text { pain scores, physical } \\
\text { quality of life scores, } \\
\text { and mental quality of } \\
\text { life scores of the } \\
\text { NSCLBP patients who } \\
\text { received the MBSR } \\
\text { compared to those in } \\
\text { the control group. }\end{array}$ \\
\hline
\end{tabular}




\begin{tabular}{|c|c|c|c|c|}
\hline Article Citation & $\begin{array}{l}\text { Method of } \\
\text { Research }\end{array}$ & Sample & Main Findings & $\begin{array}{c}\text { Significance Levels } \\
\text { of Findings }\end{array}$ \\
\hline $\begin{array}{l}\text { Beaulac, J. \& Bailly, } \\
\text { M. (2015). } \\
\text { Mindfulness-based } \\
\text { stress reduction: Pilot } \\
\text { study of a treatment } \\
\text { group for patients with } \\
\text { chronic pain in a } \\
\text { primary care setting. } \\
\text { Primary Health Care } \\
\text { Research \& } \\
\text { Development, 16, } \\
\text { 424-428. }\end{array}$ & $\begin{array}{l}\text { Adult patients with } \\
\text { chronic pain were } \\
\text { recruited from } 20 \\
\text { clinics in Winnipeg, } \\
\text { Manitoba that are part } \\
\text { of a collaborative care } \\
\text { program and outcome } \\
\text { measures were } \\
\text { administered at } \\
\text { baseline and program } \\
\text { completion. }\end{array}$ & $\begin{array}{l}\text { There were } 2 \text { groups: } \\
\text { the first group included } \\
18 \text { patients and the } \\
\text { second group included } \\
8 \text { patients. Subjects } \\
\text { included } 26 \text { patients } \\
\text { living with chronic } \\
\text { pain (e.g., lower back } \\
\text { pain, fibromyalgia, } \\
\text { arthritis). } 17 \text { patients } \\
\text { completed evaluation } \\
\text { measures at the end of } \\
\text { the programme. }\end{array}$ & $\begin{array}{l}\text { The intervention } \\
\text { revealed significant } \\
\text { and/or clinically } \\
\text { relevant improvements } \\
\text { in level of pain } \\
\text { disability, } \\
\text { psychological distress, } \\
\text { engagement in life } \\
\text { activities, willingness } \\
\text { to experience pain, and } \\
\text { subjective rating of } \\
\text { current pain. }\end{array}$ & $\begin{array}{l}\text { At baseline, Group } 1 \\
\text { reported a significantly } \\
\text { higher level of } \\
\text { disability related to the } \\
\text { PDI self-care category } \\
\text { compared with Group } \\
\text { 2. There was a } \\
\text { significant different on } \\
\text { subjective rating of } \\
\text { current pain, with } \\
\text { completes reporting a } \\
\text { lower baseline level of } \\
\text { pain as compared with } \\
\text { non-completers. By } \\
\text { using } 12 \text { paired } \\
\text { samples' t-tests, } \\
\text { significant } \\
\text { improvements were } \\
\text { found for level of pain } \\
\text { disability related to } \\
\text { recreation and overall } \\
\text { total disability, level of } \\
\text { psychological distress, } \\
\text { level of engagement in } \\
\text { life activities, and } \\
\text { willingness to } \\
\text { experience pain. }\end{array}$ \\
\hline $\begin{array}{l}\text { Cathcart, S., Galatis, } \\
\text { N., Immink, M., } \\
\text { Proeve, M., Petkov, J. } \\
\text { (2014). Brief } \\
\text { mindfulness-based } \\
\text { therapy for chronic } \\
\text { tension-type headache: } \\
\text { A randomized } \\
\text { controlled pilot study. } \\
\text { Behavioural and } \\
\text { Cognitive } \\
\text { Psychotherapy, 42, } \\
\text { 1-15. }\end{array}$ & $\begin{array}{l}\text { Conducted a } \\
\text { randomized controlled } \\
\text { trial for brief } \\
\text { Mindfulness-Based } \\
\text { Therapy (MBT); 6- } \\
\text { session, } 3 \text { weeks; for } \\
\text { Chronic Tension-Type } \\
\text { Headache (CTH). }\end{array}$ & $\begin{array}{l}\text { Total sample of } 42 \\
\text { patients who met the } \\
\text { International } \\
\text { Classification of } \\
\text { Headache Disorders } \\
\text { (ICHD-II) criteria for } \\
\text { Chronic Tension-Type } \\
\text { Headache and were } \\
\text { aged } 18-65 \text { years. }\end{array}$ & $\begin{array}{l}\text { Brief MBT may be an } \\
\text { effective intervention } \\
\text { for CTH. }\end{array}$ & $\begin{array}{l}\text { The results indicate a } \\
\text { statistically significant } \\
\text { reduction in headache } \\
\text { frequency in the } \\
\text { treatment but not } \\
\text { control group. Found } \\
\text { an increase in the } \\
\text { mindfulness facet of } \\
\text { Observe in the } \\
\text { treatment but not the } \\
\text { wait-list group (but no } \\
\text { improvement in overall } \\
\text { mindfulness). }\end{array}$ \\
\hline $\begin{array}{l}\text { Cherkin DC, Sherman } \\
\text { KJ, Balderson BH, et } \\
\text { al. Effect of } \\
\text { Mindfulness-Based } \\
\text { Stress Reduction vs } \\
\text { Cognitive Behavioral } \\
\text { Therapy or Usual Care } \\
\text { on Back Pain and } \\
\text { Functional Limitations } \\
\text { in Adults With Chronic } \\
\text { Low Back Pain: A } \\
\text { Randomized Clinical } \\
\text { Trial. JAMA. } \\
\text { 2016;315(12): } \\
\text { 1240-1249. }\end{array}$ & $\begin{array}{l}3 \text { groups: CBT, MBSR, } \\
\text { and usual care received } \\
\text { treatment for } 8 \text { weeks. }\end{array}$ & $\begin{array}{l}342 \text { adults with chronic } \\
\text { low back pain in } \\
\text { Washington State. }\end{array}$ & $\begin{array}{l}\text { Treatment with MBSR } \\
\text { or CBT, compared with } \\
\text { usual care, resulted in } \\
\text { greater improvement in } \\
\text { back pain and } \\
\text { functional limitations } \\
\text { at } 26 \text { weeks, with no } \\
\text { significant differences } \\
\text { in outcomes between } \\
\text { MBSR and CBT. } \\
\text { MBSR may be an } \\
\text { effective treatment for } \\
\text { patients with CLBP. }\end{array}$ & $\begin{array}{l}\text { In intent-to-treat } \\
\text { analyses at } 26 \text { weeks, } \\
\text { the percentage of } \\
\text { participants with } \\
\text { clinically meaningful } \\
\text { improvement on the } \\
\text { Roland Disability } \\
\text { Questionnaire (RDQ) } \\
\text { was higher for those } \\
\text { who received MBSR } \\
(60.5 \%) \text { and CBT } \\
(57.7 \%) \text { than for usual } \\
\text { care }(44.1 \%) \text {. }\end{array}$ \\
\hline
\end{tabular}




\begin{tabular}{|c|c|c|c|c|}
\hline Article Citation & $\begin{array}{l}\text { Method of } \\
\text { Research }\end{array}$ & Sample & Main Findings & $\begin{array}{c}\text { Significance Levels } \\
\text { of Findings }\end{array}$ \\
\hline $\begin{array}{l}\text { Esmer, G. E., Blum, J., } \\
\text { Rulf, J., Pier, J. (2011). } \\
\text { Mindfulness-based } \\
\text { stress reduction for } \\
\text { failed back surgery } \\
\text { syndrome: A } \\
\text { randomized controlled } \\
\text { trial. Journal of the } \\
\text { American Osteopathic } \\
\text { Association 110(11), } \\
\text { 646-652. }\end{array}$ & $\begin{array}{l}2 \text { groups: control group } \\
\text { (traditional therapy } \\
\text { only) and MBSR } \\
\text { therapy plus traditional } \\
\text { therapy group, for } 8 \\
\text { weeks. At enrollment } \\
\text { and at } 12 \text {-week follow- } \\
\text { up, all participants } \\
\text { completed } \\
\text { questionnaires on pain, } \\
\text { quality of life, } \\
\text { functionality, analgesic } \\
\text { use, and sleep quality. } \\
\text { Patients in the } \\
\text { intervention group also } \\
\text { completed } \\
\text { questionnaires at 40- } \\
\text { week follow-up. }\end{array}$ & $\begin{array}{l}220 \text { invitation letters } \\
\text { were sent to a random } \\
\text { selection of patients } \\
\text { with persistent leg } \\
\text { pain, back pain, or both } \\
\text { despite having } \\
\text { lumbosacral spinal } \\
\text { surgery in the past } 2 \\
\text { years. Patients were } \\
\text { recruited from } \\
\text { Portland, Maine. A } \\
\text { sampling of } 25 \text { patients } \\
\text { was chosen arbitrarily. }\end{array}$ & $\begin{array}{l}\text { MBSR can be a useful } \\
\text { treatment for patients } \\
\text { with Failed Back } \\
\text { Surgery Syndrome } \\
\text { (FBSS). }\end{array}$ & $\begin{array}{l}\text { At 12-week follow-up, } \\
\text { patients in the MBSR } \\
\text { group had a mean 4- } \\
\text { point increase (on an } \\
\text { 18-point scale) in pain } \\
\text { acceptance and quality } \\
\text { of life on the Chronic } \\
\text { Pain Assessment } \\
\text { Questionnaire, a mean } \\
\text { 3-point decrease (on a } \\
\text { 24-point scale) in } \\
\text { functional limitation on } \\
\text { the Roland-Morris } \\
\text { Disability } \\
\text { Questionnaire, a mean } \\
\text { 5-point reduction (on a } \\
\text { 30-point scale) in pain } \\
\text { level on the Summary } \\
\text { Visual Analog Scale } \\
\text { for Pain, a mean 1- } \\
\text { point reduction (on a 4- } \\
\text { point scale) in } \\
\text { frequency of use and } \\
\text { potency of analgesics } \\
\text { used for pain and } \\
\text { recorded on logs, and a } \\
\text { mean 1-point increase } \\
\text { (on a 5-point scale) in } \\
\text { sleep quality on the } \\
\text { abridged Pittsburgh } \\
\text { Sleep Quality } \\
\text { Inventory. }\end{array}$ \\
\hline $\begin{array}{l}\text { Fjorback, L. O., } \\
\text { Arendt, M., Ornbol, E., } \\
\text { Walach, H., Rehfeld, } \\
\text { E., Schroder, A., Fink, } \\
\text { P. (2013). Mindfulness } \\
\text { therapy for } \\
\text { somatization disorder } \\
\text { and functional somatic } \\
\text { syndromes - } \\
\text { Randomized trial with } \\
\text { one-year follow-up. } \\
\text { Journal of } \\
\text { Psychosomatic } \\
\text { Research } 74,31-40 .\end{array}$ & $\begin{array}{l}2 \text { groups: mindfulness } \\
\text { therapy (MBSR and } \\
\text { some cognitive } \\
\text { behavioral therapy } \\
\text { elements for Bodily } \\
\text { Distress Syndrome } \\
\text { [BDS]) group and } \\
\text { enhanced treatment as } \\
\text { usual (2-hour specialist } \\
\text { medical care and brief } \\
\text { CBT for BDS). The } \\
\text { primary outcome } \\
\text { measure was change in } \\
\text { physical health (SF-36 } \\
\text { Physical Component } \\
\text { Summary) from } \\
\text { baseline to 15-month } \\
\text { follow-up. }\end{array}$ & $\begin{array}{l}119 \text { patients in } \\
\text { Denmark who had } \\
\text { chronic (at least } 2 \\
\text { years) of the multi- } \\
\text { organ type BDS with } \\
\text { moderate to severe } \\
\text { impairment in daily } \\
\text { living. }\end{array}$ & $\begin{array}{l}\text { Mindfulness therapy is } \\
\text { an acceptable treatment } \\
\text { for people with BDS. } \\
\text { Mindfulness therapy is } \\
\text { comparable to } \\
\text { enhanced treatment as } \\
\text { usual in improving } \\
\text { quality of life and } \\
\text { symptoms. }\end{array}$ & $\begin{array}{l}\text { The study is negative } \\
\text { as they could not } \\
\text { demonstrate a different } \\
\text { development over time } \\
\text { of } \\
\text { SF-36 Physical } \\
\text { Component Summary } \\
\text { (PCS) for mindfulness } \\
\text { therapy and treatment } \\
\text { as usual. }\end{array}$ \\
\hline
\end{tabular}




\begin{tabular}{|c|c|c|c|c|}
\hline Article Citation & $\begin{array}{l}\text { Method of } \\
\text { Research }\end{array}$ & Sample & Main Findings & $\begin{array}{c}\text { Significance Levels } \\
\text { of Findings }\end{array}$ \\
\hline $\begin{array}{l}\text { Garland, E. L., } \\
\text { Gaylord, S. A., } \\
\text { Palsson, O., Faurot, K., } \\
\text { Mann, J. D., } \\
\text { Whitehead, W. E. } \\
\text { (2012). Therapeutic } \\
\text { mechanisms of a } \\
\text { mindfulness-based } \\
\text { treatment for IBS: } \\
\text { effects on visceral } \\
\text { sensitivity, } \\
\text { catastrophizing, and } \\
\text { affective processing of } \\
\text { pain sensations. J } \\
\text { Behav Med, 35(6), } \\
\text { 591-602. }\end{array}$ & $\begin{array}{l}2 \text { groups: MT group or } \\
\text { a social support group, } \\
\text { for } 8 \text { weeks. A } \\
\text { theoretically grounded, } \\
\text { multivariate path } \\
\text { model tested } \\
\text { therapeutic mediators } \\
\text { of the effect of MT on } \\
\text { IBS severity and } \\
\text { quality of life. }\end{array}$ & $\begin{array}{l}75 \text { female IBS patients } \\
\text { who met Rome II } \\
\text { diagnostic criteria for } \\
\text { IBS. }\end{array}$ & $\begin{array}{l}\text { MT appears to target } \\
\text { and eliminate the } \\
\text { underlying pathogenic } \\
\text { mechanisms of IBS }\end{array}$ & $\begin{array}{l}\text { Participants in the MT } \\
\text { group experienced } \\
\text { significant } \\
\text { improvements in IBS } \\
\text { severity, IBS-related } \\
\text { quality of life, } \\
\text { nonreactivity, } \\
\text { nonjudgmental of } \\
\text { experience, observing } \\
\text { and attending to } \\
\text { experience, visceral } \\
\text { sensitivity, pain } \\
\text { catastrophizing, } \\
\text { psychiatric distress, } \\
\text { and cognitive coping } \\
\text { via reinterpretation of } \\
\text { pain sensations from } \\
\text { pre- to post-treatment. } \\
\text { No significant changes } \\
\text { were found among } \\
\text { social support group } \\
\text { participants. }\end{array}$ \\
\hline $\begin{array}{l}\text { Grossman, P., } \\
\text { Tiefenthaler-Gilmer, } \\
\text { U., Raysz, A., Kesper, } \\
\text { U. (2007). Mindfulness } \\
\text { training as an } \\
\text { intervention for } \\
\text { fibromyalgia: Evidence } \\
\text { of postintervention and } \\
\text { 3-year follow-up } \\
\text { benefits in well-being. } \\
\text { Psychotherapy and } \\
\text { Psychosomatics 76, } \\
\text { 226-233. }\end{array}$ & $\begin{array}{l}\text { A quasi-experimental } \\
\text { study with an MBSR } \\
\text { group and an active } \\
\text { social support group } \\
\text { for } 8 \text { weeks. Self- } \\
\text { report measures were } \\
\text { validated German } \\
\text { inventories and } \\
\text { included the following } \\
\text { scales: visual analog } \\
\text { pain, pain perception, } \\
\text { coping with pain, a } \\
\text { symptom checklist and } \\
\text { QoL. Pre- and post } \\
\text { intervention } \\
\text { measurements were } \\
\text { made and a 3-year } \\
\text { follow-up was carried } \\
\text { out on a sub-group of } \\
26 \text { participants. }\end{array}$ & $\begin{array}{l}58 \text { female patients with } \\
\text { fibromyalgia (I think in } \\
\text { Germany, it doesn't } \\
\text { explicitly say but they } \\
\text { used German validated } \\
\text { inventories) }\end{array}$ & $\begin{array}{l}\text { MBSR is a potential } \\
\text { long-term benefit for } \\
\text { female fibromyalgia } \\
\text { patients. }\end{array}$ & $\begin{array}{l}\text { Pre- to postintervention } \\
\text { analyses indicated } \\
\text { MBSR to provide } \\
\text { significantly greater } \\
\text { benefits than the } \\
\text { control intervention on } \\
\text { most dimensions } \\
\text { including visual analog } \\
\text { pain, QoL subscales, } \\
\text { coping with pain, } \\
\text { anxiety, depression and } \\
\text { somatic complaints } \\
\text { (Cohen d effect size, } \\
\text { 0.40-1.10). 3-year } \\
\text { follow-up analyses of } \\
\text { MBSR participants } \\
\text { indicated sustained } \\
\text { benefits for these same } \\
\text { measures (effect size, } \\
0.50-0.65 \text { ). }\end{array}$ \\
\hline $\begin{array}{l}\text { Lush, E., Salmon, P., } \\
\text { Floyd, A., Studts, J.L., } \\
\text { Weissbecker, I., } \\
\text { Sephton, S.E. (2009). } \\
\text { Mindfulness } \\
\text { meditation for } \\
\text { symptom reduction in } \\
\text { fibromyalgia: } \\
\text { Psychophysiological } \\
\text { correlates. J Clin } \\
\text { Psychol Med Settings } \\
\text { 16, 200-207. } \\
\text { (Didn't use this in my } \\
\text { thesis) }\end{array}$ & $\begin{array}{l}\text { Participants responded } \\
\text { to a TV news } \\
\text { appearance, } \\
\text { newspaper, and radio } \\
\text { ads. Effects on anxiety, } \\
\text { depressive symptoms, } \\
\text { and SNS activation } \\
\text { measures were tested } \\
\text { before and after MBSR } \\
\text { using a within-subjects } \\
\text { design. }\end{array}$ & $\begin{array}{l}\text { Female patients with } \\
\text { fibromyalgia aged } 18+ \\
\text { years. }\end{array}$ & $\begin{array}{l}\text { Basal sympathetic } \\
\text { (SNS) activation was } \\
\text { reduced following } \\
\text { MBSR treatment. } \\
\text { Reductions of } \\
\text { psychophysiological } \\
\text { recordings (SCL) } \\
\text { occurred not only } \\
\text { during the body scan, } \\
\text { but also during the } \\
\text { resting baseline and } \\
\text { follow-up phases of } \\
\text { recording. }\end{array}$ & $\begin{array}{l}\text { Mean BAI pre- } \\
\text { treatment scores were } \\
16.9 \text { with SD } 11.2 \text {, } \\
\text { indicating baseline } \\
\text { scores were on the } \\
\text { threshold of 'moderate' } \\
\text { anxiety, while post- } \\
\text { treatment BAI scores } \\
(\mathrm{M}=14.3, \mathrm{SD}=8.1) \\
\text { were in the 'mild' } \\
\text { range. }\end{array}$ \\
\hline
\end{tabular}




\begin{tabular}{|c|c|c|c|c|}
\hline Article Citation & $\begin{array}{l}\text { Method of } \\
\text { Research }\end{array}$ & Sample & Main Findings & $\begin{array}{c}\text { Significance Levels } \\
\text { of Findings }\end{array}$ \\
\hline $\begin{array}{l}\text { Morone, N. E., Lynch, } \\
\text { C. S., Greco, C. M., } \\
\text { Tindle, H. A., Weiner, } \\
\text { D. K. (2008). "I felt } \\
\text { like a new person." } \\
\text { The effects of } \\
\text { mindfulness meditation } \\
\text { on older adults with } \\
\text { chronic pain: } \\
\text { qualitative narrative } \\
\text { analysis of diary } \\
\text { entries. The Journal of } \\
\text { Pain: Official Journal } \\
\text { of the American Pain } \\
\text { Society, 9(9), 841-848. }\end{array}$ & $\begin{array}{l}\text { Conducted a } \\
\text { qualitative study based } \\
\text { on grounded theory } \\
\text { and used content } \\
\text { analysis of diary } \\
\text { entries from older } \\
\text { adults who had } \\
\text { participated in a } \\
\text { clinical trial of an } 8 \\
\text { week mindfulness } \\
\text { meditation program. }\end{array}$ & $\begin{array}{l}27 \text { adults who were } 65 \\
\text { years and older with } \\
\text { chronic low back pain } \\
\text { (CLBP) of at least } \\
\text { moderate severity and } \\
\text { of at least } 3 \text { months } \\
\text { duration. }\end{array}$ & $\begin{array}{l}\text { Several themes were } \\
\text { identified related to } \\
\text { pain reduction, } \\
\text { improved attention, } \\
\text { improved sleep, and } \\
\text { achieving well-being } \\
\text { resulting from } \\
\text { mindfulness meditation } \\
\text { that suggest it has } \\
\text { promising potential as } \\
\text { a non-pharmacologic } \\
\text { treatment of chronic } \\
\text { pain for older adults. }\end{array}$ & $\begin{array}{l}\text { Not applicable because } \\
\text { the authors used } \\
\text { grounded theory to } \\
\text { analyze diary entries. }\end{array}$ \\
\hline $\begin{array}{l}\text { Omidi, A., \& Zargar, F. } \\
\text { (2014). Effect of } \\
\text { mindfulness-based } \\
\text { stress reduction on } \\
\text { pain severity and } \\
\text { mindful awareness in } \\
\text { patients with tension } \\
\text { headache: A } \\
\text { randomized controlled } \\
\text { clinical trial." Nursing } \\
\text { and Midwifery Studies, } \\
\text { 3(3). }\end{array}$ & $\begin{array}{l}2 \text { groups: MBSR group } \\
\text { and treatment as usual } \\
\text { (TAU) group, for } 8 \\
\text { weeks. Diary scale for } \\
\text { measuring headache } \\
\text { and Mindful Attention } \\
\text { Awareness Scale } \\
\text { (MAAS) were } \\
\text { administered at } \\
\text { baseline, } \\
\text { posttreatment, and 3- } \\
\text { month follow-up for } \\
\text { both groups. The data } \\
\text { was analyzed by } \\
\text { repeated measures } \\
\text { analysis of variance. }\end{array}$ & $\begin{array}{l}60 \text { patients diagnosed } \\
\text { with tension-type } \\
\text { headache in Kashan, } \\
\text { Iran. }\end{array}$ & $\begin{array}{l}\text { MBSR can reduce pain } \\
\text { and improve } \\
\text { mindfulness skills in } \\
\text { patients with tension } \\
\text { headache. MBSR is an } \\
\text { effective } \\
\text { psychotherapy for } \\
\text { treatment of illnesses } \\
\text { with pain. }\end{array}$ & $\begin{array}{l}\text { Results found } \\
\text { significant reductions } \\
\text { in pain severity; mean } \\
\text { of pain severity before } \\
\text { intervention was } 7.36 \\
\text { and after intervention } \\
\text { and follow-up was } 5.62 \\
\text { and } 6.07 \text {, respectively. } \\
\text { In addition, the MBSR } \\
\text { group showed higher } \\
\text { scores in mindful } \\
\text { awareness in } \\
\text { comparison with the } \\
\text { control group at } \\
\text { posttest and follow-up; } \\
\text { mean of mindful } \\
\text { awareness before } \\
\text { intervention was } 34.9 \\
\text { and after intervention } \\
\text { and follow-up changed } \\
\text { to } 53.8 \text { and } 40.7 \text {, } \\
\text { respectively. }\end{array}$ \\
\hline $\begin{array}{l}\text { Plews-Ogan, M., } \\
\text { Owens, J. E., } \\
\text { Goodman, M., Wolfe, } \\
\text { P., Schorling, J., } \\
\text { (2005). A pilot study } \\
\text { evaluating } \\
\text { mindfulness-based } \\
\text { stress reduction and } \\
\text { massage for the } \\
\text { management of chronic } \\
\text { pain. Journal of } \\
\text { General Internal } \\
\text { Medicine, 20(12), } \\
\text { 1136-1138. }\end{array}$ & $\begin{array}{l}\text { Randomized trial } \\
\text { comparing MBSR or } \\
\text { massage with standard } \\
\text { care. }\end{array}$ & $\begin{array}{l}30 \text { patients with } \\
\text { musculoskeletal pain. }\end{array}$ & $\begin{array}{l}\text { MBSR may be more } \\
\text { effective and longer- } \\
\text { lasting for mood } \\
\text { improvement while } \\
\text { massage may be more } \\
\text { effective for reducing } \\
\text { pain. MBSR may have } \\
\text { a positive impact on } \\
\text { mental health in these } \\
\text { patients, an effect that } \\
\text { seems to persist after } \\
\text { the classes are } \\
\text { completed. }\end{array}$ & $\begin{array}{l}\text { At week } 8 \text {, the massage } \\
\text { group had average } \\
\text { difference scores for } \\
\text { pain unpleasantness of } \\
2.9 \text { and mental health } \\
\text { status of } 13.6 \\
\text { compared with } 0.13 \\
\text { and } 3.9 \text { for the standard } \\
\text { care group. These } \\
\text { differences were no } \\
\text { longer significant at } \\
\text { week } 12 \text {. There were } \\
\text { no significant } \\
\text { differences in the pain } \\
\text { outcomes for the } \\
\text { MBSR group. At week } \\
12 \text {, the mean change in } \\
\text { mental health status for } \\
\text { the MBSR group was } \\
10.2 \text { compared with } \\
-1.7 \text { in the standard } \\
\text { care group. }\end{array}$ \\
\hline
\end{tabular}




\begin{tabular}{|c|c|c|c|c|}
\hline Article Citation & $\begin{array}{l}\text { Method of } \\
\text { Research }\end{array}$ & Sample & Main Findings & $\begin{array}{c}\text { Significance Levels } \\
\text { of Findings }\end{array}$ \\
\hline $\begin{array}{l}\text { Pradhan, E. K., } \\
\text { Baumgarten, M., } \\
\text { Langenberg, P., } \\
\text { Handwerger, B., } \\
\text { Gilpin, A. K., Magyari, } \\
\text { T., Hochberg, M. C., } \\
\text { Berman, B. M. (2007). } \\
\text { Effect of Mindfulness- } \\
\text { Based Stress Reduction } \\
\text { in Rheumatoid } \\
\text { Arthritis patients. } \\
\text { Arthritis \& } \\
\text { Rheumatism (Arthritis } \\
\text { Care \& Research), } \\
\text { 57(7), 1134-1142. }\end{array}$ & $\begin{array}{l}2 \text { groups: MBSR group } \\
\text { where participants } \\
\text { attended an } 8 \text {-week } \\
\text { course and 4-month } \\
\text { maintenance program, } \\
\text { or a waitlist control } \\
\text { group where } \\
\text { participants attended } \\
\text { all assessment visits } \\
\text { and received MBSR } \\
\text { for free of charge after } \\
\text { study end. Participants } \\
\text { received usual care } \\
\text { from their } \\
\text { rheumatologists } \\
\text { throughout the trial. } \\
\text { Self-report measures } \\
\text { were used to evaluate } \\
\text { depressive symptoms, } \\
\text { psychological distress, } \\
\text { well-being, and } \\
\text { mindfulness. } \\
\text { Evaluation of RA } \\
\text { disease activity } \\
\text { included examination } \\
\text { by a physician. } \\
\text { Adjusted means and } \\
\text { mean changes in } \\
\text { outcomes were } \\
\text { estimated in mixed } \\
\text { model repeated } \\
\text { measures analyses. }\end{array}$ & $\begin{array}{l}63 \text { adult ( } 18 \text { years and } \\
\text { older) patients with } \\
\text { rheumatoid arthritis } \\
\text { (RA) in Baltimore, } \\
\text { Maryland. }\end{array}$ & $\begin{array}{l}\text { An 8-week MBSR } \\
\text { class was not } \\
\text { associated with change } \\
\text { in depressive } \\
\text { symptoms or other } \\
\text { outcomes at 2-month } \\
\text { follow-up. Significant } \\
\text { improvements in } \\
\text { psychological distress } \\
\text { and well-being were } \\
\text { observed following } \\
\text { MBSR plus a 4-month } \\
\text { program of continued } \\
\text { reinforcement. } \\
\text { Mindfulness } \\
\text { meditation may } \\
\text { complement medical } \\
\text { disease management } \\
\text { by improving } \\
\text { psychological distress } \\
\text { and strengthening well- } \\
\text { being in patients with } \\
\text { RA. }\end{array}$ & $\begin{array}{l}\text { At } 2 \text { months, there } \\
\text { were no statistically } \\
\text { significant differences } \\
\text { between groups in any } \\
\text { outcomes. At } 6 \text { months, } \\
\text { there was significant } \\
\text { improvement in } \\
\text { psychological distress } \\
\text { and well being, and } \\
\text { marginally significant } \\
\text { improvement in } \\
\text { depressive symptoms } \\
\text { and mindfulness. There } \\
\text { was a } 35 \% \text { reduction in } \\
\text { psychological distress } \\
\text { among those treated. } \\
\text { The intervention had } \\
\text { no impact on RA } \\
\text { disease activity. }\end{array}$ \\
\hline $\begin{array}{l}\text { Rahmani, S., } \\
\text { Talepasand, S., } \\
\text { Ghanbary-Motlagh A. } \\
\text { (2014). Comparison of } \\
\text { Effectiveness of the } \\
\text { Metacognition } \\
\text { Treatment and the } \\
\text { Mindfulness-Based } \\
\text { Stress Reduction } \\
\text { Treatment on Global } \\
\text { and Specific Life } \\
\text { Quality of Women with } \\
\text { Breast Cancer. Iranian } \\
\text { Journal of Cancer } \\
\text { Prevention, 7(4), } \\
\text { 184-196. }\end{array}$ & $\begin{array}{l}3 \text { groups: meta- } \\
\text { cognition treatment, } \\
\text { MBSR group, and } \\
\text { control group in a } \\
\text { quasi-experimental } \\
\text { design with pre-test } \\
\text { and post-test. } \\
\text { Participants completed } \\
\text { global life quality in } \\
\text { cancer patient's } \\
\text { questionnaire and } \\
\text { specific quality of life } \\
\text { in breast cancer } \\
\text { patient's questionnaire. } \\
\text { Data were analyzed } \\
\text { using the multivariate } \\
\text { repeated measures } \\
\text { model. }\end{array}$ & $\begin{array}{l}36 \text { women with breast } \\
\text { cancer in Tehran, Iran. }\end{array}$ & $\begin{array}{l}\text { MBSR can be effective } \\
\text { in improving global } \\
\text { and specific life quality } \\
\text { of women with breast } \\
\text { cancer and is a } \\
\text { selective method for } \\
\text { improving quality of } \\
\text { life in patients. MBSR } \\
\text { excelled in functions } \\
\text { and roles, fatigue, pain, } \\
\text { future perspective and } \\
\text { treatment side effects } \\
\text { symptoms at the end of } \\
\text { treatment and follow- } \\
\text { up in comparison to the } \\
\text { metacognition } \\
\text { treatment. }\end{array}$ & $\begin{array}{l}\text { Global life quality } \\
\text { scores in experimental } \\
\text { groups in emotional, } \\
\text { cognitive, and social } \\
\text { functions increased } \\
\text { from pre-test to post- } \\
\text { test and have relative } \\
\text { stability in follow-up. } \\
\text { In the MBSR group, } \\
\text { role function scores } \\
\text { increased from pre-test } \\
\text { to post-test and have } \\
\text { stability in follow-up. } \\
\text { The greatest increase in } \\
\text { scores is in the } \\
\text { emotional dimension } \\
\text { with MBSR. } \\
\text { Comparison of means } \\
\text { shows in fatigue and } \\
\text { pain dimensions the } \\
\text { greatest decrease is in } \\
\text { MBSR but in sleep } \\
\text { disorder the greatest } \\
\text { decrease is in } \\
\text { metacognition } \\
\text { treatment. }\end{array}$ \\
\hline
\end{tabular}




\begin{tabular}{|c|c|c|c|c|}
\hline Article Citation & $\begin{array}{l}\text { Method of } \\
\text { Research }\end{array}$ & Sample & Main Findings & $\begin{array}{c}\text { Significance Levels } \\
\text { of Findings }\end{array}$ \\
\hline $\begin{array}{l}\text { Rosenzweig, S., } \\
\text { Greeson, J. M., Reibel, } \\
\text { D. K., Green, J. S., } \\
\text { Jasser, S. A., Beasley, } \\
\text { D. (2010). } \\
\quad \text { Mindfulness- } \\
\text { based stress reduction } \\
\text { for chronic pain } \\
\text { conditions: Variation in } \\
\text { treatment outcomes } \\
\text { and role of home } \\
\text { meditation practice. } \\
\text { Journal of } \\
\text { Psychosomatic } \\
\text { Research } 68,29-36 .\end{array}$ & $\begin{array}{l}\text { A longitudinal } \\
\text { investigation of } \\
\text { chronic pain patients } \\
\text { using MBSR. } \\
\text { Measures include the } \\
\text { Short-Form } 36 \text { Health } \\
\text { Survey and Symptom } \\
\text { Checklist-90-Revised. } \\
\text { Paired t tests were used } \\
\text { to compare pre-post } \\
\text { changes on outcome } \\
\text { measures. Differences } \\
\text { in treatment effect } \\
\text { sizes were compared as } \\
\text { a function of chronic } \\
\text { pain condition. } \\
\text { Correlations were } \\
\text { examined between } \\
\text { outcome parameters } \\
\text { and home meditation } \\
\text { practice. }\end{array}$ & $\begin{array}{l}133 \text { participants at a } \\
\text { university-based } \\
\text { Integrative Medicine } \\
\text { Center. } 51 \text { participants } \\
\text { presented chronic neck } \\
\text { and/or back pain, } \\
\text { making these the most } \\
\text { prevalent pain } \\
\text { conditions. In } \\
\text { descending order of } \\
\text { frequency, other pain } \\
\text { conditions included } \\
\text { chronic headaches/ } \\
\text { migraines (n=34), } \\
\text { arthritis (n=32), } \\
\text { fibromyalgia (n=27), } \\
\text { and variable other } \\
\text { conditions of lesser } \\
\text { prevalence. } 52 \text { patients } \\
\text { had } 2+\text { comorbid pain } \\
\text { conditions. }\end{array}$ & $\begin{array}{l}\text { MBSR treatment } \\
\text { effects on pain, } \\
\text { HRQoL and } \\
\text { psychological well- } \\
\text { being vary as a } \\
\text { function of chronic } \\
\text { pain condition and } \\
\text { compliance with home } \\
\text { meditation practice. }\end{array}$ & $\begin{array}{l}\text { Patient subgroup } \\
\text { analyses revealed that } \\
\text { HRQoL outcomes } \\
\text { differed substantially } \\
\text { across chronic pain } \\
\text { conditions. } \\
\text { Comparison of } \\
\text { treatment effects across } \\
\text { SCL-90-R sub scales } \\
\text { revealed that chronic } \\
\text { pain subgroups } \\
\text { generally experienced } \\
\text { medium to large } \\
\text { magnitude reductions } \\
\text { in symptoms of } \\
\text { psychological distress. }\end{array}$ \\
\hline $\begin{array}{l}\text { Schmidt, S., Grossman, } \\
\text { P., Schwarzer, B., Jena, } \\
\text { S., Naumann, J., } \\
\text { Walach, H. (2011). } \\
\text { Treating fibromyalgia } \\
\text { with mindfulness- } \\
\text { based stress reduction: } \\
\text { Results from a 3-armed } \\
\text { randomized } \\
\text { controlled trial. PAIN } \\
\text { 152, 361-369. }\end{array}$ & $\begin{array}{l}3 \text { groups: MBSR, an } \\
\text { active control } \\
\text { procedure controlling } \\
\text { for nonspecific effects } \\
\text { of MBSR, and a wait } \\
\text { list. }\end{array}$ & $\begin{array}{l}177 \text { female patients } \\
\text { with fibromyalgia in } \\
\text { Germany. }\end{array}$ & $\begin{array}{l}\text { The primary outcome } \\
\text { was health-related } \\
\text { quality of life } \\
\text { (HRQoL) and in each } \\
\text { set of analyses, no } \\
\text { group effects upon } \\
\text { HRQoL were found = } \\
\text { MBSR is not an } \\
\text { effective treatment for } \\
\text { women with } \\
\text { fibromyalgia. MBSR } \\
\text { did reduce anxiety and } \\
\text { increase mindfulness. } \\
\text { On average, patients of } \\
\text { all groups showed } \\
\text { slight improvements } \\
\text { over the course of the } \\
\text { trial. }\end{array}$ & $\begin{array}{l}\text { The active treatment } \\
\text { groups showed greater } \\
\text { post intervention } \\
\text { reductions in anxiety } \\
\text { than the wait-list } \\
\text { patients. Patients in the } \\
\text { MBSR group rated } \\
\text { themselves higher on } \\
\text { the mindfulness scale } \\
\text { (FMI) than patients in } \\
\text { the active control } \\
\text { group. }\end{array}$ \\
\hline $\begin{array}{l}\text { Sephton, S. E., } \\
\text { Salmon, P., } \\
\text { Weissbecker, I., Ulmer, } \\
\text { C., Floyd, A., Hoover, } \\
\text { K., Studts, J. L. (2007). } \\
\text { Mindfulness } \\
\text { meditation alleviates } \\
\text { depressive symptoms } \\
\text { in women with } \\
\text { fibromyalgia: Results } \\
\text { of a randomized } \\
\text { clinical trial. Arthritis } \\
\text { \& Rheumatism, 57(1), } \\
\text { 77-85. }\end{array}$ & $\begin{array}{l}2 \text { groups: treatment (8- } \\
\text { week MBSR group) or } \\
\text { waiting-list control } \\
\text { group. } 8 \text { weekly } 2.5- \\
\text { hour sessions were led } \\
\text { by a licensed clinical } \\
\text { psychologist with } \\
\text { mindfulness training. } \\
\text { Somatic and cognitive } \\
\text { symptoms of } \\
\text { depression were } \\
\text { assessed using the } \\
\text { Beck Depression } \\
\text { Inventory administered } \\
\text { at baseline, } \\
\text { immediately } \\
\text { postprogram, and at } \\
\text { followup } 2 \text { months } \\
\text { after the intervention. }\end{array}$ & $\begin{array}{l}91 \text { female patients with } \\
\text { fibromyalgia }\end{array}$ & $\begin{array}{l}\text { MBSR alleviated } \\
\text { depressive symptoms } \\
\text { among patients with } \\
\text { fibromyalgia. } \\
\text { Participants who still } \\
\text { meditated at the end of } \\
\text { the study had the } \\
\text { greatest reduction of } \\
\text { depressive symptoms. }\end{array}$ & $\begin{array}{l}\text { Depressive symptoms } \\
\text { improved significantly } \\
\text { in treatment versus } \\
\text { control participants } \\
\text { over } 3 \text { assessments. }\end{array}$ \\
\hline
\end{tabular}




\section{Appendix 2: Results of MBSR on outcome measures}

\begin{tabular}{|c|c|c|c|c|c|}
\hline Article Citation & Illness/Disease & Pain & $\begin{array}{l}\text { Quality of Life/ } \\
\text { Well-Being }\end{array}$ & $\begin{array}{c}\text { Psychological } \\
\text { Distress } \\
\text { (Depression \& } \\
\text { Anxiety) }\end{array}$ & $\begin{array}{l}\text { Negative } \\
\text { Findings }\end{array}$ \\
\hline $\begin{array}{l}\text { Arefnasab, Z., } \\
\text { Ghanei, M., } \\
\text { Noorbala, A. A., } \\
\text { Alipour, A., } \\
\text { Babamahmoodi, } \\
\text { F., } \\
\text { Babamahmoodi, } \\
\text { A., Salehi, M. } \\
\text { (2013). Effect of } \\
\text { Mindfulness Based } \\
\text { Stress Reduction } \\
\text { on Quality of Life } \\
\text { (SF-36) and } \\
\text { Spirometry } \\
\text { Parameters, in } \\
\text { Chemically } \\
\text { Pulmonary Injured } \\
\text { Veterans. Iranian } \\
\text { Journal of Public } \\
\text { Health, 42(9), } \\
\text { 1026-1033. }\end{array}$ & $\begin{array}{l}\text { Pulmonary (lung) } \\
\text { injury by mustard } \\
\text { gas }\end{array}$ & + & + & & $\begin{array}{l}\text { No significant } \\
\text { improvements in } \\
\text { physical } \\
\text { functioning and } \\
\text { general health } \\
\text { perception. }\end{array}$ \\
\hline $\begin{array}{l}\text { Banth, S. \& } \\
\text { Ardebil, M. D. } \\
\text { (2015). } \\
\text { Effectiveness of } \\
\text { mindfulness } \\
\text { mediation on pain } \\
\text { and quality of life } \\
\text { of patients with } \\
\text { chronic low back } \\
\text { pain. International } \\
\text { Journal of Yoga, } \\
\text { 8(2), 128-133. }\end{array}$ & $\begin{array}{c}\text { Nonspecific } \\
\text { chronic low back } \\
\text { pain (NSCLBP) }\end{array}$ & + & + & & \\
\hline $\begin{array}{l}\text { Beaulac, J. \& } \\
\text { Bailly, M. (2015). } \\
\text { Mindfulness-based } \\
\text { stress reduction: } \\
\text { Pilot study of a } \\
\text { treatment group } \\
\text { for patients with } \\
\text { chronic pain in a } \\
\text { primary care } \\
\text { setting. Primary } \\
\text { Health Care } \\
\text { Research \& } \\
\text { Development, 16, } \\
\text { 424-428. }\end{array}$ & $\begin{array}{l}\text { Chronic pain (e.g., } \\
\text { lower back pain, } \\
\text { fibromyalgia, } \\
\text { arthritis) }\end{array}$ & + & + & + & \\
\hline
\end{tabular}




\begin{tabular}{|c|c|c|c|c|c|}
\hline Article Citation & Illness/Disease & Pain & $\begin{array}{l}\text { Quality of Life/ } \\
\text { Well-Being }\end{array}$ & $\begin{array}{c}\text { Psychological } \\
\text { Distress } \\
\text { (Depression \& } \\
\text { Anxiety) }\end{array}$ & $\begin{array}{l}\text { Negative } \\
\text { Findings }\end{array}$ \\
\hline $\begin{array}{l}\text { Cathcart, S., } \\
\text { Galatis, N., } \\
\text { Immink, M., } \\
\text { Proeve, M., } \\
\text { Petkov, J. (2014). } \\
\text { Brief mindfulness- } \\
\text { based therapy for } \\
\text { chronic tension- } \\
\text { type headache: A } \\
\text { randomized } \\
\text { controlled pilot } \\
\text { study. Behavioural } \\
\text { and Cognitive } \\
\text { Psychotherapy, 42, } \\
\text { 1-15. }\end{array}$ & $\begin{array}{l}\text { Chronic tension- } \\
\text { type headaches } \\
\text { (CTH) }\end{array}$ & + & & - & $\begin{array}{l}\text { No significant } \\
\text { improvements for } \\
\text { headache intensity } \\
\text { or duration. } \\
\text { Number of } \\
\text { sessions attended } \\
\text { did not correlate } \\
\text { with post treatment } \\
\text { headache or } \\
\text { mindfulness. Did } \\
\text { not improve } \\
\text { overall } \\
\text { mindfulness, only } \\
\text { the mindfulness } \\
\text { facet of Observe } \\
\text { was improved in } \\
\text { the MBT group. } \\
\text { No change in } \\
\text { stress, depression, } \\
\text { or anxiety in either } \\
\text { group. }\end{array}$ \\
\hline $\begin{array}{l}\text { Cherkin DC, } \\
\text { Sherman KJ, } \\
\text { Balderson BH, et } \\
\text { al. Effect of } \\
\text { Mindfulness- } \\
\text { Based Stress } \\
\text { Reduction vs } \\
\text { Cognitive } \\
\text { Behavioral } \\
\text { Therapy or Usual } \\
\text { Care on Back Pain } \\
\text { and Functional } \\
\text { Limitations in } \\
\text { Adults With } \\
\text { Chronic Low Back } \\
\text { Pain: A } \\
\text { Randomized } \\
\text { Clinical Trial. } \\
\text { JAMA. } \\
\text { 2016;315(12): } \\
\text { 1240-1249. }\end{array}$ & $\begin{array}{l}\text { Chronic low back } \\
\text { pain (CLBP) }\end{array}$ & + & + & + & $\begin{array}{l}\text { CBT was superior } \\
\text { to MBSR on the } \\
\text { depression } \\
\text { measure at } 8 \\
\text { weeks, but the } \\
\text { mean difference } \\
\text { between groups } \\
\text { was small. }\end{array}$ \\
\hline $\begin{array}{l}\text { Esmer, G. E., } \\
\text { Blum, J., Rulf, J., } \\
\text { Pier, J. (2011). } \\
\text { Mindfulness-based } \\
\text { stress reduction for } \\
\text { failed back surgery } \\
\text { syndrome: A } \\
\text { randomized } \\
\text { controlled trial. } \\
\text { Journal of the } \\
\text { American } \\
\text { Osteopathic } \\
\text { Association } \\
\text { 110(11), 646-652. }\end{array}$ & $\begin{array}{l}\text { Persistent leg pain, } \\
\text { back pain, or both } \\
\text { despite a history of } \\
\text { lumbosacral spine } \\
\text { surgery within the } \\
\text { last two years }\end{array}$ & + & + & & \\
\hline
\end{tabular}




\begin{tabular}{|c|c|c|c|c|c|}
\hline Article Citation & Illness/Disease & Pain & $\begin{array}{l}\text { Quality of Life/ } \\
\text { Well-Being }\end{array}$ & $\begin{array}{c}\text { Psychological } \\
\text { Distress } \\
\text { (Depression \& } \\
\text { Anxiety) }\end{array}$ & $\begin{array}{l}\text { Negative } \\
\text { Findings }\end{array}$ \\
\hline $\begin{array}{l}\text { Fjorback, L. O., } \\
\text { Arendt, M., } \\
\text { Ornbol, E., } \\
\text { Walach, H., } \\
\text { Rehfeld, E., } \\
\text { Schroder, A., Fink, } \\
\text { P. (2013). } \\
\text { Mindfulness } \\
\text { therapy for } \\
\text { somatization } \\
\text { disorder and } \\
\text { functional somatic } \\
\text { syndromes - } \\
\text { Randomized trial } \\
\text { with one-year } \\
\text { follow-up. Journal } \\
\text { of Psychosomatic } \\
\text { Research 74, } \\
\text { 31-40. }\end{array}$ & $\begin{array}{c}\text { Somatization } \\
\text { disorder and } \\
\text { functional somatic } \\
\text { syndromes (e.g., } \\
\text { fibromyalgia, IBS, } \\
\text { and chronic fatigue } \\
\text { syndrome) }\end{array}$ & + & & + & $\begin{array}{l}\text { The study is } \\
\text { negative as they } \\
\text { could not } \\
\text { demonstrate a } \\
\text { different } \\
\text { development over } \\
\text { time of SF-36 } \\
\text { Physical } \\
\text { Component } \\
\text { Summary (PCS) } \\
\text { for mindfulness } \\
\text { therapy and } \\
\text { treatment as usual. } \\
\text { However, the } \\
\text { mindfulness } \\
\text { therapy group } \\
\text { significantly } \\
\text { changed at the end } \\
\text { of treatment, and } \\
\text { this change } \\
\text { remained at } 15- \\
\text { month follow-up, } \\
\text { whereas no } \\
\text { significant change } \\
\text { was seen in } \\
\text { enhanced } \\
\text { treatment as usual } \\
\text { group until at the } \\
15 \text {-month } \\
\text { followup. On the } \\
\text { SF-36 sub scales } \\
\text { and symptom } \\
\text { outcomes such as } \\
\text { bodily pain, } \\
\text { physical } \\
\text { sypmtoms, illness } \\
\text { worry, and anxiety } \\
\text { and depression, } \\
\text { both groups } \\
\text { registered } \\
\text { statistically and } \\
\text { clinically } \\
\text { significant } \\
\text { improvements } \\
\text { across time, but } \\
\text { similar to the main } \\
\text { results, no } \\
\text { significant } \\
\text { between-group } \\
\text { differences were } \\
\text { observed. }\end{array}$ \\
\hline
\end{tabular}




\begin{tabular}{|c|c|c|c|c|c|}
\hline Article Citation & Illness/Disease & Pain & $\begin{array}{l}\text { Quality of Life/ } \\
\text { Well-Being }\end{array}$ & $\begin{array}{l}\text { Psychological } \\
\text { Distress } \\
\text { (Depression \& } \\
\text { Anxiety) }\end{array}$ & $\begin{array}{l}\text { Negative } \\
\text { Findings }\end{array}$ \\
\hline $\begin{array}{l}\text { Garland, E. L., } \\
\text { Gaylord, S. A., } \\
\text { Palsson, O., } \\
\text { Faurot, K., Mann, } \\
\text { J. D., Whitehead, } \\
\text { W. E. (2012). } \\
\text { Therapeutic } \\
\text { mechanisms of a } \\
\text { mindfulness-based } \\
\text { treatment for IBS: } \\
\text { effects on visceral } \\
\text { sensitivity, } \\
\text { catastrophizing, } \\
\text { and affective } \\
\text { processing of pain } \\
\text { sensations. J } \\
\text { Behav Med, 35(6), } \\
\text { 591-602. }\end{array}$ & $\begin{array}{l}\text { Irritable Bowel } \\
\text { Syndrome (IBS) }\end{array}$ & + & + & + & \\
\hline $\begin{array}{l}\text { Grossman, P., } \\
\text { Tiefenthaler- } \\
\text { Gilmer, U., Raysz, } \\
\text { A., Kesper, U. } \\
\text { (2007). } \\
\text { Mindfulness } \\
\text { training as an } \\
\text { intervention for } \\
\text { fibromyalgia: } \\
\text { Evidence of } \\
\text { postintervention } \\
\text { and 3-year follow- } \\
\text { up benefits in } \\
\text { well-being. } \\
\text { Psychotherapy and } \\
\text { Psychosomatics } \\
\text { 76, 226-233. }\end{array}$ & Fibromyalgia & + & + & + & \\
\hline $\begin{array}{l}\text { Lush, E., Salmon, } \\
\text { P., Floyd, A., } \\
\text { Studts, J.L., } \\
\text { Weissbecker, I., } \\
\text { Sephton, S.E. } \\
\text { (2009). } \\
\text { Mindfulness } \\
\text { meditation for } \\
\text { symptom } \\
\text { reduction in } \\
\text { fibromyalgia: } \\
\text { Psychophysiologic } \\
\text { al correlates. J } \\
\text { Clin Psychol Med } \\
\text { Settings 16, } \\
\text { 200-207. }\end{array}$ & Fibromyalgia & & & - & $\begin{array}{l}\text { Pre- versus post- } \\
\text { treatment } \\
\text { reductions in } \\
\text { anxiety and } \\
\text { depressive } \\
\text { symptoms did not } \\
\text { reach significance. }\end{array}$ \\
\hline
\end{tabular}




\begin{tabular}{|c|c|c|c|c|c|}
\hline Article Citation & Illness/Disease & Pain & $\begin{array}{l}\text { Quality of Life/ } \\
\text { Well-Being }\end{array}$ & $\begin{array}{l}\text { Psychological } \\
\text { Distress } \\
\text { (Depression \& } \\
\text { Anxiety) }\end{array}$ & $\begin{array}{l}\text { Negative } \\
\text { Findings }\end{array}$ \\
\hline $\begin{array}{l}\text { Morone, N. E., } \\
\text { Lynch, C. S., } \\
\text { Greco, C. M., } \\
\text { Tindle, H. A., } \\
\text { Weiner, D. K. } \\
\text { (2008). "I felt like } \\
\text { a new person." } \\
\text { The effects of } \\
\text { mindfulness } \\
\text { meditation on } \\
\text { older adults with } \\
\text { chronic pain: } \\
\text { qualitative } \\
\text { narrative analysis } \\
\text { of diary entries. } \\
\text { The Journal of } \\
\text { Pain: Official } \\
\text { Journal of the } \\
\text { American Pain } \\
\text { Society, 9(9), } \\
\text { 841-848. }\end{array}$ & $\begin{array}{l}\text { Chronic low back } \\
\text { pain (CLBP) }\end{array}$ & + & + & & \\
\hline $\begin{array}{l}\text { Omidi, A., \& } \\
\text { Zargar, F. (2014). } \\
\text { Effect of } \\
\text { mindfulness-based } \\
\text { stress reduction on } \\
\text { pain severity and } \\
\text { mindful awareness } \\
\text { in patients with } \\
\text { tension headache: } \\
\text { A randomized } \\
\text { controlled clinical } \\
\text { trial.” Nursing and } \\
\text { Midwifery Studies, } \\
\text { 3(3). }\end{array}$ & Tension headache & + & & & \\
\hline $\begin{array}{l}\text { Plews-Ogan, M., } \\
\text { Owens, J. E., } \\
\text { Goodman, M., } \\
\text { Wolfe, P., } \\
\text { Schorling, J., } \\
\text { (2005). A pilot } \\
\text { study evaluating } \\
\text { mindfulness-based } \\
\text { stress reduction } \\
\text { and massage for } \\
\text { the management of } \\
\text { chronic pain. } \\
\text { Journal of General } \\
\text { Internal Medicine, } \\
\text { 20(12), 1136-1138. }\end{array}$ & $\begin{array}{c}\text { Chronic } \\
\text { musculoskeletal } \\
\text { pain }\end{array}$ & - & & + & $\begin{array}{l}\text { There were no } \\
\text { significant } \\
\text { differences in pain } \\
\text { outcomes for the } \\
\text { MBSR group. } \\
\text { Changes in the } \\
\text { global mental } \\
\text { health SF-12 } \\
\text { scores were } \\
\text { observed while } \\
\text { there were no } \\
\text { significant changes } \\
\text { in the global } \\
\text { physical health } \\
\text { SF-12 scores. }\end{array}$ \\
\hline
\end{tabular}




\begin{tabular}{|c|c|c|c|c|c|}
\hline Article Citation & Illness/Disease & Pain & $\begin{array}{l}\text { Quality of Life/ } \\
\text { Well-Being }\end{array}$ & $\begin{array}{l}\text { Psychological } \\
\text { Distress } \\
\text { (Depression \& } \\
\text { Anxiety) }\end{array}$ & $\begin{array}{l}\text { Negative } \\
\text { Findings }\end{array}$ \\
\hline $\begin{array}{l}\text { Pradhan, E. K., } \\
\text { Baumgarten, M., } \\
\text { Langenberg, P., } \\
\text { Handwerger, B., } \\
\text { Gilpin, A. K., } \\
\text { Magyari, T., } \\
\text { Hochberg, M. C., } \\
\text { Berman, B. M. } \\
\text { (2007). Effect of } \\
\text { Mindfulness- } \\
\text { Based Stress } \\
\text { Reduction in } \\
\text { Rheumatoid } \\
\text { Arthritis patients. } \\
\text { Arthritis \& } \\
\text { Rheumatism } \\
\text { (Arthritis Care \& } \\
\text { Research), 57(7), } \\
\text { 1134-1142. }\end{array}$ & $\begin{array}{l}\text { Rheumatoid } \\
\text { arthritis (RA) }\end{array}$ & & + & - to + & $\begin{array}{l}\text { MBSR had no } \\
\text { effect on } \\
\text { depressive } \\
\text { symptoms or other } \\
\text { outcomes at 2- } \\
\text { month follow-up; } \\
\text { it wasn't until 4- } \\
\text { month follow-up } \\
\text { that significant } \\
\text { improvements in } \\
\text { psychological } \\
\text { distress and well- } \\
\text { being were } \\
\text { observed. No } \\
\text { effect on RA } \\
\text { disease activity. }\end{array}$ \\
\hline $\begin{array}{l}\text { Rahmani, S., } \\
\text { Talepasand, S., } \\
\text { Ghanbary-Motlagh } \\
\text { A. (2014). } \\
\text { Comparison of } \\
\text { Effectiveness of } \\
\text { the Metacognition } \\
\text { Treatment and the } \\
\text { Mindfulness- } \\
\text { Based Stress } \\
\text { Reduction } \\
\text { Treatment on } \\
\text { Global and } \\
\text { Specific Life } \\
\text { Quality of Women } \\
\text { with Breast } \\
\text { Cancer. Iranian } \\
\text { Journal of Cancer } \\
\text { Prevention, 7(4), } \\
\text { 184-196. }\end{array}$ & Breast cancer & + & + & + & $\begin{array}{l}\text { MBSR had a } \\
\text { negative effect on } \\
\text { physical function } \\
\text { (no effect on } \\
\text { physical } \\
\text { symptoms). }\end{array}$ \\
\hline
\end{tabular}




\begin{tabular}{|c|c|c|c|c|c|}
\hline Article Citation & Illness/Disease & Pain & $\begin{array}{l}\text { Quality of Life/ } \\
\text { Well-Being }\end{array}$ & $\begin{array}{c}\text { Psychological } \\
\text { Distress } \\
\text { (Depression \& } \\
\text { Anxiety) }\end{array}$ & $\begin{array}{l}\text { Negative } \\
\text { Findings }\end{array}$ \\
\hline $\begin{array}{l}\text { Rosenzweig, S., } \\
\text { Greeson, J. M., } \\
\text { Reibel, D. K., } \\
\text { Green, J. S., } \\
\text { Jasser, S. A., } \\
\text { Beasley, D. } \\
\text { (2010). } \\
\text { Mindfulness-based } \\
\text { stress reduction for } \\
\text { chronic pain } \\
\text { conditions: } \\
\text { Variation in } \\
\text { treatment } \\
\text { outcomes and role } \\
\text { of home } \\
\text { meditation } \\
\text { practice. Journal } \\
\text { of Psychosomatic } \\
\text { Research 68, } \\
\text { 29-36. }\end{array}$ & $\begin{array}{l}\text { Chronic neck and/ } \\
\text { or back pain, } \\
\text { chronic headaches/ } \\
\text { migraines, } \\
\text { arthritis, } \\
\text { fibromyalgia, } \\
\text { variable other } \\
\text { conditions of } \\
\text { lesser prevalence, } \\
\text { and two or more } \\
\text { comorbid pain } \\
\text { conditions }\end{array}$ & + & + & + & $\begin{array}{l}\text { Patients with } \\
\text { fibromyalgia, } \\
\text { arthritis, and } \\
\text { chronic headache/ } \\
\text { migraine } \\
\text { experienced lesser } \\
\text { improvements in } \\
\text { pain severity and } \\
\text { functional } \\
\text { limitations due to } \\
\text { pain compared to } \\
\text { patients with } \\
\text { chronic back/neck } \\
\text { pain or those with } \\
\text { 2+ comorbid pain } \\
\text { conditions. } \\
\text { Patients with } \\
\text { chronic headache/ } \\
\text { migraine reported } \\
\text { the smallest } \\
\text { magnitude } \\
\text { improvement in } \\
\text { HRQoL following } \\
\text { MBSR. }\end{array}$ \\
\hline $\begin{array}{l}\text { Schmidt, S., } \\
\text { Grossman, P., } \\
\text { Schwarzer, B., } \\
\text { Jena, S., Naumann, } \\
\text { J., Walach, H. } \\
\text { (2011). Treating } \\
\text { fibromyalgia with } \\
\text { mindfulness-based } \\
\text { stress reduction: } \\
\text { Results from a 3- } \\
\text { armed } \\
\text { randomized } \\
\text { controlled trial. } \\
\text { PAIN 152, } \\
\text { 361-369. }\end{array}$ & Fibromyalgia & & - & + & $\begin{array}{l}\text { No group effects } \\
\text { upon HRQoL were } \\
\text { found. Therefore } \\
\text { the MBSR } \\
\text { intervention did } \\
\text { not prove to be } \\
\text { better than a } \\
\text { simple wait-list } \\
\text { procedure or an } \\
\text { active control } \\
\text { condition, so } \\
\text { MBSR is not an } \\
\text { effective treatment } \\
\text { for women with } \\
\text { fibromyalgia. }\end{array}$ \\
\hline
\end{tabular}




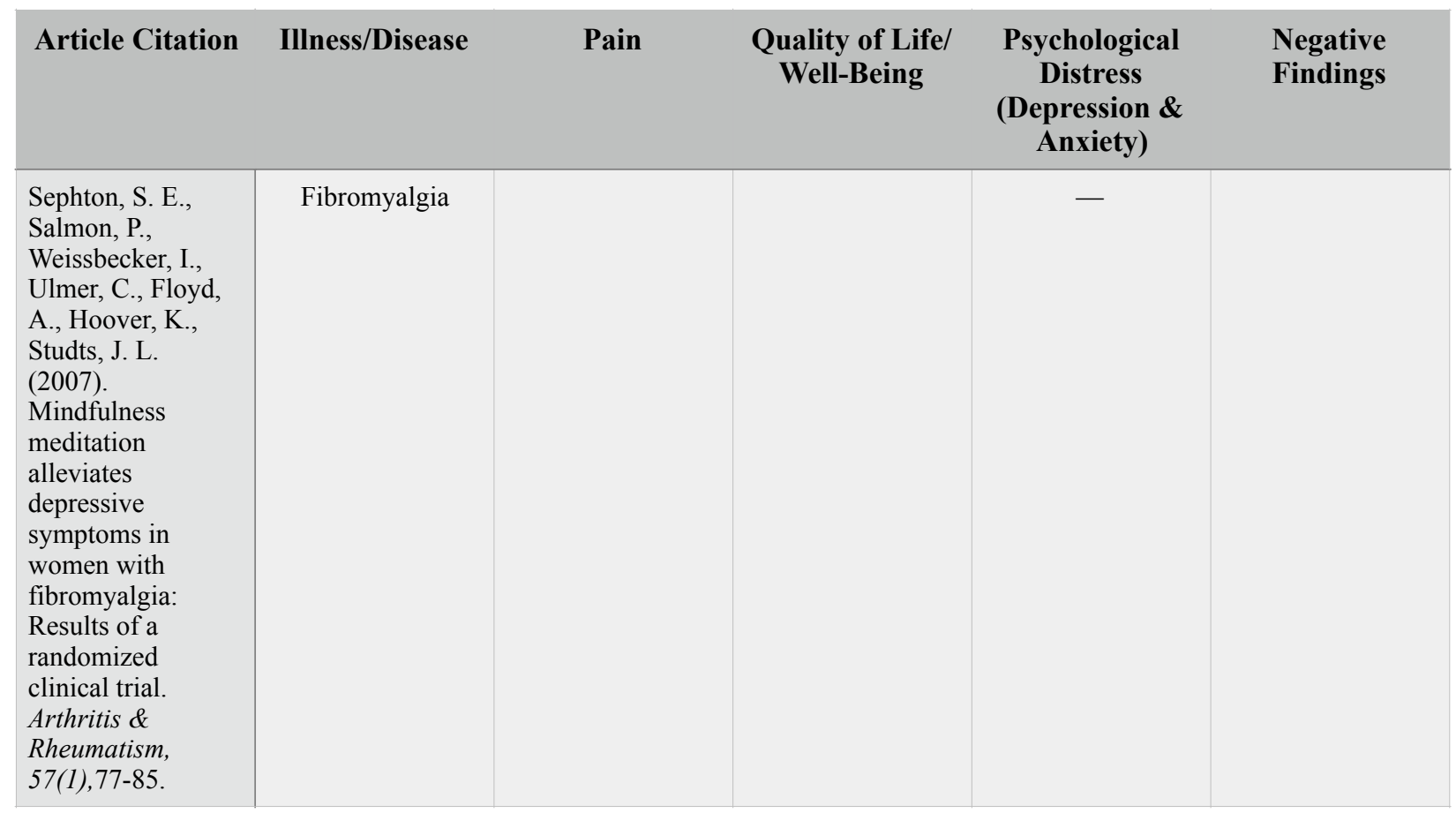

Note: Data collected for Appendix 2 was retrieved from each of the 18 articles examined based on whether each article found positive or negative findings for each of the outcome measures (i.e., pain, quality of life or well-being, and psychological distress including depression and anxiety). 


\section{Appendix 3: Demographic information of patient populations in MBSR studies}

\begin{tabular}{|c|c|c|c|c|c|}
\hline Article Citation & Gender & Age Range & $\begin{array}{c}\text { Ethnic/Racial } \\
\text { Group }\end{array}$ & $\begin{array}{l}\text { Non-English } \\
\text { Speaking }\end{array}$ & SES \\
\hline $\begin{array}{l}\text { Arefnasab, Z., } \\
\text { Ghanei, M., } \\
\text { Noorbala, A. A., } \\
\text { Alipour, A., } \\
\text { Babamahmoodi, } \\
\text { F., } \\
\text { Babamahmoodi, } \\
\text { A., Salehi, M. } \\
\text { (2013). Effect of } \\
\text { Mindfulness Based } \\
\text { Stress Reduction } \\
\text { on Quality of Life } \\
\text { (SF-36) and } \\
\text { Spirometry } \\
\text { Parameters, in } \\
\text { Chemically } \\
\text { Pulmonary Injured } \\
\text { Veterans. Iranian } \\
\text { Journal of Public } \\
\text { Health, 42(9), } \\
\text { 1026-1033. }\end{array}$ & Male & & White & & $\begin{array}{l}\text { Veterans from } \\
\text { Iran-Iraq War }\end{array}$ \\
\hline $\begin{array}{l}\text { Banth, S. \& } \\
\text { Ardebil, M. D. } \\
\text { (2015). } \\
\text { Effectiveness of } \\
\text { mindfulness } \\
\text { mediation on pain } \\
\text { and quality of life } \\
\text { of patients with } \\
\text { chronic low back } \\
\text { pain. International } \\
\text { Journal of Yoga, } \\
\text { 8(2), 128-133. }\end{array}$ & Female & $30-45$ & $\begin{array}{l}\text { Did not state, } \\
\text { assuming Iranian } \\
\text { since the study } \\
\text { takes place in Iran }\end{array}$ & Language: Persian & $\begin{array}{l}\text { Educated at least } \\
\text { up to high school }\end{array}$ \\
\hline $\begin{array}{l}\text { Beaulac, J. \& } \\
\text { Bailly, M. (2015). } \\
\text { Mindfulness-based } \\
\text { stress reduction: } \\
\text { Pilot study of a } \\
\text { treatment group } \\
\text { for patients with } \\
\text { chronic pain in a } \\
\text { primary care } \\
\text { setting. Primary } \\
\text { Health Care } \\
\text { Research \& } \\
\text { Development, 16, } \\
\text { 424-428. }\end{array}$ & $\begin{array}{l}\text { Mostly female: } 22 \\
\text { female patients } \\
\text { and } 4 \text { male } \\
\text { patients }\end{array}$ & $33-71$ & $\begin{array}{l}\text { White. Study takes } \\
\text { place in Canada }\end{array}$ & & $\begin{array}{l}\text { "Broad socio- } \\
\text { economic } \\
\text { representation" }\end{array}$ \\
\hline
\end{tabular}




\begin{tabular}{|c|c|c|c|c|c|}
\hline Article Citation & Gender & Age Range & $\begin{array}{c}\text { Ethnic/Racial } \\
\text { Group }\end{array}$ & $\begin{array}{l}\text { Non-English } \\
\text { Speaking }\end{array}$ & SES \\
\hline $\begin{array}{l}\text { Cathcart, S., } \\
\text { Galatis, N., } \\
\text { Immink, M., } \\
\text { Proeve, M., } \\
\text { Petkov, J. (2014). } \\
\text { Brief mindfulness- } \\
\text { based therapy for } \\
\text { chronic tension- } \\
\text { type headache: A } \\
\text { randomized } \\
\text { controlled pilot } \\
\text { study. Behavioural } \\
\text { and Cognitive } \\
\text { Psychotherapy, 42, } \\
\text { 1-15. }\end{array}$ & & $\begin{array}{l}\text { Inclusion criteria } \\
\text { was } 18-65 \text { years, } \\
\text { but did not state } \\
\text { actually age range } \\
\text { of participants } \\
\text { selected }\end{array}$ & $\begin{array}{l}\text { Does not say, but } \\
\text { the study took } \\
\text { place in Australia }\end{array}$ & & \\
\hline $\begin{array}{l}\text { Cherkin DC, } \\
\text { Sherman KJ, } \\
\text { Balderson BH, et } \\
\text { al. Effect of } \\
\text { Mindfulness- } \\
\text { Based Stress } \\
\text { Reduction vs } \\
\text { Cognitive } \\
\text { Behavioral } \\
\text { Therapy or Usual } \\
\text { Care on Back Pain } \\
\text { and Functional } \\
\text { Limitations in } \\
\text { Adults With } \\
\text { Chronic Low Back } \\
\text { Pain: A } \\
\text { Randomized } \\
\text { Clinical Trial. } \\
\text { JAMA. } \\
\text { 2016;315(12): } \\
\text { 1240-1249. }\end{array}$ & $\begin{array}{l}224(65.7 \%) \text { were } \\
\text { women }\end{array}$ & $20-70$ years & $\begin{array}{l}\text { Most patients were } \\
\text { white (278 or } \\
82.5 \%), 13 \text { asians } \\
(3.9 \%), 11 \text { african } \\
\text { americans }(3.3 \%) \text {, } \\
\text { and } 23 \text { hispanics } \\
(6.8 \%) .\end{array}$ & $\begin{array}{l}\text { Does not say, but } \\
\text { the study took } \\
\text { place in the U.S. }\end{array}$ & $\begin{array}{l}\text { Most patients were } \\
\text { college graduates } \\
\text { (201 or } 58.9 \%) \text {, } \\
114 \text { had some } \\
\text { college or } \\
\text { vocational school } \\
(33.4 \%) \text {, and } 26 \\
\text { had a high school } \\
\text { education or less } \\
(7.6 \%) \text {. Most } \\
\text { patients were } \\
\text { employed ( } 263 \text { or } \\
77.1 \%) \text {. Most } \\
\text { patients had a } \\
\text { family income of } \\
\text { more than } \$ 55,000 \\
(206 \text { or } 62.6 \%) .\end{array}$ \\
\hline $\begin{array}{l}\text { Esmer, G. E., } \\
\text { Blum, J., Rulf, J., } \\
\text { Pier, J. (2011). } \\
\text { Mindfulness-based } \\
\text { stress reduction for } \\
\text { failed back surgery } \\
\text { syndrome: A } \\
\text { randomized } \\
\text { controlled trial. } \\
\text { Journal of the } \\
\text { American } \\
\text { Osteopathic } \\
\text { Association } \\
\text { 110(11), 646-652. }\end{array}$ & & & & $\begin{array}{l}\text { Does not say, but } \\
\text { the study took } \\
\text { place in Portland, } \\
\text { Maine }\end{array}$ & \\
\hline
\end{tabular}




\begin{tabular}{|c|c|c|c|c|c|}
\hline Article Citation & Gender & Age Range & $\begin{array}{c}\text { Ethnic/Racial } \\
\text { Group }\end{array}$ & $\begin{array}{l}\text { Non-English } \\
\text { Speaking }\end{array}$ & SES \\
\hline $\begin{array}{l}\text { Fjorback, L. O., } \\
\text { Arendt, M., } \\
\text { Ornbol, E., } \\
\text { Walach, H., } \\
\text { Rehfeld, E., } \\
\text { Schroder, A., Fink, } \\
\text { P. (2013). } \\
\text { Mindfulness } \\
\text { therapy for } \\
\text { somatization } \\
\text { disorder and } \\
\text { functional somatic } \\
\text { syndromes - } \\
\text { Randomized trial } \\
\text { with one-year } \\
\text { follow-up. Journal } \\
\text { of Psychosomatic } \\
\text { Research 74, } \\
\text { 31-40. }\end{array}$ & & $\begin{array}{l}\text { Required to be } \\
20-50 \text { years of age, } \\
\text { but didn't state } \\
\text { exact ages of } \\
\text { participants. }\end{array}$ & $\begin{array}{l}\text { Does not say, but } \\
\text { assuming White/ } \\
\text { Danish since it } \\
\text { took place in } \\
\text { Denmark }\end{array}$ & & $\begin{array}{l}\text { Patients were } \\
\text { referred from both } \\
\text { urban and rural } \\
\text { areas covering a } \\
\text { population of } \\
\text { approximately } 3 \\
\text { million people (but } \\
\text { doesn't talk about } \\
\text { the SES of the } \\
\text { people actually } \\
\text { included in the } \\
\text { study). }\end{array}$ \\
\hline $\begin{array}{l}\text { Garland, E. L., } \\
\text { Gaylord, S. A., } \\
\text { Palsson, O., } \\
\text { Faurot, K., Mann, } \\
\text { J. D., Whitehead, } \\
\text { W. E. (2012). } \\
\text { Therapeutic } \\
\text { mechanisms of a } \\
\text { mindfulness-based } \\
\text { treatment for IBS: } \\
\text { effects on visceral } \\
\text { sensitivity, } \\
\text { catastrophizing, } \\
\text { and affective } \\
\text { processing of pain } \\
\text { sensations. J } \\
\text { Behav Med, 35(6), } \\
\text { 591-602. }\end{array}$ & Female & $18-75$ years & $\begin{array}{l}\text { Does not say, but } \\
\text { the study took } \\
\text { place in North } \\
\text { Carolina }\end{array}$ & & \\
\hline $\begin{array}{l}\text { Grossman, P., } \\
\text { Tiefenthaler- } \\
\text { Gilmer, U., Raysz, } \\
\text { A., Kesper, U. } \\
\text { (2007). } \\
\text { Mindfulness } \\
\text { training as an } \\
\text { intervention for } \\
\text { fibromyalgia: } \\
\text { Evidence of } \\
\text { postintervention } \\
\text { and 3-year follow- } \\
\text { up benefits } \\
\quad \text { in well- } \\
\text { being. } \\
\text { Psychotherapy and } \\
\text { Psychosomatics } \\
\text { 76, 226-233. }\end{array}$ & $\begin{array}{l}\text { Female. Men were } \\
\text { excluded because } \\
\text { only } 1 \text { man } \\
\text { volunteered }\end{array}$ & $\begin{array}{l}\text { The MBSR group } \\
\text { was significantly } \\
\text { older }(54.4+/-8.3 \\
\text { SD years) than the } \\
\text { control group } \\
(48.8+/-9.1 \text { years; } \\
\text { p }<0.05) \text {. }\end{array}$ & $\begin{array}{l}\text { Does not say, } \\
\text { assuming White/ } \\
\text { German }\end{array}$ & German & $\begin{array}{l}\text { Educational levels } \\
\text { are as follows: } \\
\text { basic education ( } 9 \\
\text { years) or less and/ } \\
\text { or trade school, } \\
35 \% \text {; mid-level } \\
\text { secondary school } \\
\text { (10 years), } 43 \% \text {; } \\
\text { college- } \\
\text { preparatory high } \\
\text { school and/or } \\
\text { university, } 22 \% \text {. } \\
\text { Most patients were } \\
\text { unemployed, on } \\
\text { prolonged sick } \\
\text { leave or receiving } \\
\text { disability } \\
\text { insurance; only } \\
31 \% \text { reported } \\
\text { themselves as } \\
\text { actively employed. }\end{array}$ \\
\hline
\end{tabular}




\begin{tabular}{|c|c|c|c|c|c|}
\hline Article Citation & Gender & Age Range & $\begin{array}{c}\text { Ethnic/Racial } \\
\text { Group }\end{array}$ & $\begin{array}{l}\text { Non-English } \\
\text { Speaking }\end{array}$ & SES \\
\hline $\begin{array}{l}\text { Lush, E., Salmon, } \\
\text { P., Floyd, A., } \\
\text { Studts, J.L., } \\
\text { Weissbecker, I., } \\
\text { Sephton, S.E. } \\
\text { (2009). } \\
\text { Mindfulness } \\
\text { meditation for } \\
\text { symptom } \\
\text { reduction in } \\
\text { fibromyalgia: } \\
\text { Psychophysiologic } \\
\text { al correlates. J } \\
\text { Clin Psychol Med } \\
\text { Settings 16, } \\
\text { 200-207. }\end{array}$ & Female & $\begin{array}{l}\text { Ages ranged from } \\
20 \text { to } 71 \text { years } \\
(M=44) .\end{array}$ & $90.7 \%$ were white & $\begin{array}{l}\text { Does not say, but } \\
\text { the study took } \\
\text { place in the U.S. }\end{array}$ & $\begin{array}{l}\text { The average } \\
\text { participant had } 15 \\
\text { years of education. } \\
74.7 \% \text { were } \\
\text { currently } \\
\text { unemployed. }\end{array}$ \\
\hline $\begin{array}{l}\text { Morone, N. E., } \\
\text { Lynch, C. S., } \\
\text { Greco, C. M., } \\
\text { Tindle, H. A., } \\
\text { Weiner, D. K. } \\
\text { (2008). "I felt like } \\
\text { a new person." } \\
\text { The effects of } \\
\text { mindfulness } \\
\text { meditation on } \\
\text { older adults with } \\
\text { chronic pain: } \\
\text { qualitative } \\
\text { narrative analysis } \\
\text { of diary entries. } \\
\text { The Journal of } \\
\text { Pain: Official } \\
\text { Journal of the } \\
\text { American Pain } \\
\text { Society, 9(9), } \\
\text { 841-848. }\end{array}$ & $\begin{array}{l}\text { About half men } \\
\text { (13 participants) } \\
\text { and half women } \\
\text { (14 participants). }\end{array}$ & 65 years or older & $\begin{array}{l}\text { Mostly white ( } 24 \\
\text { participants) with } \\
1 \text { african american } \\
\text { and } 2 \text { asians. }\end{array}$ & $\begin{array}{l}\text { Does not say but } \\
\text { the study took } \\
\text { place in Pittsburgh, } \\
\text { Pennsylvania }\end{array}$ & $\begin{array}{l}\text { All } 27 \text { participants } \\
\text { completed high } \\
\text { school. Education } \\
\text { looked as follows: } \\
5 \text { completed high } \\
\text { school, } 4 \\
\text { completed } \\
\text { technical school, } 4 \\
\text { completed some } \\
\text { college, } 8 \\
\text { completed college, } \\
\text { and } 6 \text { completed a } \\
\text { master's or higher. } \\
\text { Income is as } \\
\text { follows: } 10 \text { had an } \\
\text { income of } \\
\$ 10,000-\$ 29,999, \\
9 \text { made } \$ 30,000- \\
\$ 59,999, \text { and } 3 \\
\text { made } \$ 60,000 \text { or } \\
\text { higher. }\end{array}$ \\
\hline $\begin{array}{l}\text { Omidi, A., \& } \\
\text { Zargar, F. (2014). } \\
\text { Effect of } \\
\text { mindfulness-based } \\
\text { stress reduction on } \\
\text { pain severity and } \\
\text { mindful awareness } \\
\text { in patients with } \\
\text { tension headache: } \\
\text { A randomized } \\
\text { controlled clinical } \\
\text { trial.” Nursing and } \\
\text { Midwifery Studies, } \\
\text { 3(3). }\end{array}$ & $\begin{array}{l}\text { Mostly female ( } 48 \\
\text { participants) with } \\
\text { only } 12 \text { men. }\end{array}$ & $\begin{array}{l}34.5+/-2.41 \text { for } \\
\text { MBSR group and } \\
32+/-3.2 \text { for TAU } \\
\text { group }\end{array}$ & $\begin{array}{l}\text { Does not say but } \\
\text { assuming Arab/ } \\
\text { Iranian since this } \\
\text { study took place in } \\
\text { Iran }\end{array}$ & & $\begin{array}{l}40 \text { of the } 60 \\
\text { patients completed } \\
\text { high school and } 20 \\
\text { of the } 60 \text { patients } \\
\text { had a bachelor's. } \\
25 \text { patients were } \\
\text { salaried employees } \\
\text { while } 35 \text { of the } \\
\text { patients were } \\
\text { housewives. }\end{array}$ \\
\hline
\end{tabular}




\begin{tabular}{|c|c|c|c|c|c|}
\hline Article Citation & Gender & Age Range & $\begin{array}{c}\text { Ethnic/Racial } \\
\text { Group }\end{array}$ & $\begin{array}{l}\text { Non-English } \\
\text { Speaking }\end{array}$ & SES \\
\hline $\begin{array}{l}\text { Plews-Ogan, M., } \\
\text { Owens, J. E., } \\
\text { Goodman, M., } \\
\text { Wolfe, P., } \\
\text { Schorling, J., } \\
\text { (2005). A pilot } \\
\text { study evaluating } \\
\text { mindfulness-based } \\
\text { stress reduction } \\
\text { and massage for } \\
\text { the management of } \\
\text { chronic } \\
\text { pain. Journal of } \\
\text { General Internal } \\
\text { Medicine, 20(12), } \\
\text { 1136-1138. }\end{array}$ & $\begin{array}{l}\text { Mostly female (33 } \\
\text { participants) with } \\
7 \text { male } \\
\text { participants. }\end{array}$ & $\begin{array}{l}\text { Average age was } \\
46.5\end{array}$ & $\begin{array}{l}\text { Doesn't say, but } \\
\text { the study took } \\
\text { place in Virginia. }\end{array}$ & & $\begin{array}{l}\text { Mean education } \\
\text { level was } 12 \text { years. } \\
\text { Half the } \\
\text { participants } \\
\text { reported incomes } \\
\text { less than } \$ 14,000 \\
\text { with an average } \\
\text { income of } \\
\$ 23,500 \text {. This } \\
\text { study specifically } \\
\text { targeted patients } \\
\text { who were likely to } \\
\text { have the most } \\
\text { barriers to } \\
\text { participation. Even } \\
\text { with this "worst- } \\
\text { case scenario" the } \\
\text { completion rate } \\
\text { was } 76 \% \text {. }\end{array}$ \\
\hline $\begin{array}{l}\text { Pradhan, E. K., } \\
\text { Baumgarten, M., } \\
\text { Langenberg, P., } \\
\text { Handwerger, B., } \\
\text { Gilpin, A. K., } \\
\text { Magyari, T., } \\
\text { Hochberg, M. C., } \\
\text { Berman, B. M. } \\
\text { (2007). Effect of } \\
\text { Mindfulness- } \\
\text { Based Stress } \\
\text { Reduction in } \\
\text { Rheumatoid } \\
\text { Arthritis patients. } \\
\text { Arthritis \& } \\
\text { Rheumatism } \\
\text { (Arthritis Care \& } \\
\text { Research), 57(7), } \\
\text { 1134-1142. }\end{array}$ & $\begin{array}{l}\text { Mostly female ( } 55 \\
\text { of } 63 \text { patients) }\end{array}$ & $\begin{array}{l}\text { Mean age was } 54 \\
\text { years }\end{array}$ & $\begin{array}{l}\text { Mostly white ( } 47 \\
\text { of } 63 \text { patients) }\end{array}$ & $\begin{array}{l}\text { Doesn't say but the } \\
\text { study took place in } \\
\text { Baltimore, } \\
\text { Maryland }\end{array}$ & $\begin{array}{l}\text { Most participants } \\
\text { had a family } \\
\text { income above } \\
\$ 50,000 \text { per year } \\
\text { ( } 39 \text { of } 63 \text { patients) } \\
\text { and possessed a } \\
\text { college degree or } \\
\text { higher ( } 39 \text { of } 63 \\
\text { patients). }\end{array}$ \\
\hline $\begin{array}{l}\text { Rahmani, S., } \\
\text { Talepasand, S., } \\
\text { Ghanbary-Motlagh } \\
\text { A. (2014). } \\
\text { Comparison of } \\
\text { Effectiveness of } \\
\text { the Metacognition } \\
\text { Treatment and the } \\
\text { Mindfulness- } \\
\text { Based Stress } \\
\text { Reduction } \\
\text { Treatment on } \\
\text { Global and } \\
\text { Specific Life } \\
\text { Quality of Women } \\
\text { with Breast } \\
\text { Cancer. Iranian } \\
\text { Journal of Cancer } \\
\text { Prevention, 7(4), } \\
\text { 184-196. }\end{array}$ & $\begin{array}{l}\text { Female because } \\
\text { the study is on } \\
\text { breast cancer }\end{array}$ & $38-49$ years & $\begin{array}{l}\text { Assuming Arab } \\
\text { since the study } \\
\text { takes place in } \\
\text { Tehran, Iran }\end{array}$ & & $\begin{array}{l}\text { Participants were } \\
\text { of average socio- } \\
\text { economic } \\
\text { condition. About } \\
20 \% \text { of them } \\
\text { graduated from } \\
\text { university and the } \\
\text { rest did not have } \\
\text { their diploma. }\end{array}$ \\
\hline
\end{tabular}




\begin{tabular}{|c|c|c|c|c|c|}
\hline Article Citation & Gender & Age Range & $\begin{array}{c}\text { Ethnic/Racial } \\
\text { Group }\end{array}$ & $\begin{array}{l}\text { Non-English } \\
\text { Speaking }\end{array}$ & SES \\
\hline $\begin{array}{l}\text { Rosenzweig, S., } \\
\text { Greeson, J. M., } \\
\text { Reibel, D. K., } \\
\text { Green, J. S., } \\
\text { Jasser, S. A., } \\
\text { Beasley, D. } \\
\text { (2010). } \\
\text { Mindfulness-based } \\
\text { stress reduction for } \\
\text { chronic pain } \\
\text { conditions: } \\
\text { Variation in } \\
\text { treatment } \\
\text { outcomes and role } \\
\text { of home } \\
\text { meditation } \\
\text { practice. Journal } \\
\text { of Psychosomatic } \\
\text { Research 68, } \\
\text { 29-36. }\end{array}$ & $\begin{array}{l}111(84 \%) \text { of } \\
\text { patients were } \\
\text { women. }\end{array}$ & $\begin{array}{l}23-78 \text { years, with a } \\
\text { mean of } 49.8 \text { years }\end{array}$ & $\begin{array}{l}123 \text { patients }(93 \%) \\
\text { were white, } 6(5 \%) \\
\text { were african } \\
\text { american, and } 3 \\
\text { were of another } \\
\text { ethnicity }(3 \%) \text {. }\end{array}$ & $\begin{array}{l}\text { Doesn't say but the } \\
\text { study took place in } \\
\text { Philadelphia }\end{array}$ & $\begin{array}{l}89 \text { participants } \\
(67 \%) \text { reported a } \\
\text { college degree or } \\
\text { postgraduate } \\
\text { education; only } 1 \\
\text { participant } \\
\text { reported less than } \\
12 \text { years of } \\
\text { education. } 72 \\
\text { (54\%) reported } \\
\text { that their } \\
\text { occupational status } \\
\text { was active } \\
\text { (working full-time, } \\
\text { working part-time, } \\
\text { enrolled as a } \\
\text { student, or } \\
\text { homemaker); } 32 \\
\text { (24\%) were } \\
\text { disabled; } 16 \text { (12\%) } \\
\text { were retired; and } 5 \\
\text { (4\%) were } \\
\text { unemployed. }\end{array}$ \\
\hline $\begin{array}{l}\text { Schmidt, S., } \\
\text { Grossman, P., } \\
\text { Schwarzer, B., } \\
\text { Jena, S., Naumann, } \\
\text { J., Walach, H. } \\
\text { (2011). Treating } \\
\text { fibromyalgia with } \\
\text { mindfulness-based } \\
\text { stress reduction: } \\
\text { Results from a 3- } \\
\text { armed } \\
\text { randomized } \\
\text { controlled trial. } \\
\text { PAIN 152, } \\
\text { 361-369. }\end{array}$ & Female & $\begin{array}{l}18-70 \text { years. The } \\
\text { mean age was } 52.5 \\
\text { years }\end{array}$ & $\begin{array}{l}\text { Does not say, } \\
\text { assuming White/ } \\
\text { German }\end{array}$ & German & $\begin{array}{l}\text { For the MBSR } \\
\text { group, } 35.8 \% \text { of } \\
\text { patients were } \\
\text { working, } 7.5 \% \\
\text { were unemployed, } \\
0 \% \text { were in school, } \\
11.3 \% \text { were } \\
\text { housewives, } \\
37.7 \% \text { were } \\
\text { retired. } \\
\text { Additionally, } 1.9 \% \\
\text { of MBSR patients } \\
\text { reported no school } \\
\text { competed, } 34 \% \\
\text { had } 9 \text { years of } \\
\text { school, } 41.5 \% \text { had } \\
11 \text { years of school, } \\
\text { and } 20.8 \% \text { were } \\
\text { college entry level. }\end{array}$ \\
\hline
\end{tabular}




\begin{tabular}{|c|c|c|c|c|c|}
\hline Article Citation & Gender & Age Range & $\begin{array}{c}\text { Ethnic/Racial } \\
\text { Group }\end{array}$ & $\begin{array}{l}\text { Non-English } \\
\text { Speaking }\end{array}$ & SES \\
\hline $\begin{array}{l}\text { Sephton, S. E., } \\
\text { Salmon, P., } \\
\text { Weissbecker, I., } \\
\text { Ulmer, C., Floyd, } \\
\text { A., Hoover, K., } \\
\text { Studts, J. L. } \\
\text { (2007). } \\
\text { Mindfulness } \\
\text { meditation } \\
\text { alleviates } \\
\text { depressive } \\
\text { symptoms in } \\
\text { women with } \\
\text { fibromyalgia: } \\
\text { Results of a } \\
\text { randomized } \\
\text { clinical trial. } \\
\text { Arthritis \& } \\
\text { Rheumatism, } \\
\text { 57(1),77-85. }\end{array}$ & Female & $\begin{array}{l}18 \text { years and older } \\
\text { Mean age was } \\
48.4 \text {. }\end{array}$ & $\begin{array}{l}\text { Mostly white } \\
(96 \%)\end{array}$ & $\begin{array}{l}\text { Doesn't say but the } \\
\text { study took place in } \\
\text { Kentucky }\end{array}$ & $\begin{array}{l}\text { Mostly employed } \\
(53 \%) \text { and } \\
\text { reported an annual } \\
\text { household income } \\
\text { between } \$ 40,000 \\
\text { and } \$ 60,000 \text {. }\end{array}$ \\
\hline
\end{tabular}

